\title{
Serum Amyloid A-Mediated Inflammasome Activation of Microglial Cells in Cerebral Ischemia
}

\author{
Jin Yu, ${ }^{1}$ Hong Zhu, ${ }^{1}$ Saeid Taheri, ${ }^{1}$ William Mondy, ${ }^{1}$ Leonardo Bonilha, ${ }^{2}$ Gayenell S. Magwood, ${ }^{3}$ Daniel Lackland, ${ }^{2}$ \\ Robert J. Adams, ${ }^{2}$ and Mark S. Kindy ${ }^{1,4,5}$ \\ ${ }^{1}$ Department of Pharmaceutical Sciences, College of Pharmacy, University of South Florida, Tampa, Florida 33612, 2Department of Neurology, College of Medicine, \\ Medical University of South Carolina, Charleston, South Carolina 29425, ${ }^{3}$ College of Nursing, Medical University of South Carolina, Charleston, South Carolina \\ 29425, ${ }^{4}$ James A. Haley Veterans Administration Medical Center, Tampa, Florida 33612, and ${ }^{5}$ Shriners Hospital for Children, Tampa, Florida 33612
}

Serum amyloid A (SAA) proteins are acute-phase reactant associated with high-density lipoprotein (HDL) particles and increase in the plasma 1000-fold during inflammation. Recent studies have implicated SAAs in innate immunity and various disorders; however, the precise mechanism eludes us. Previous studies have shown SAAs are elevated following stroke and cerebral ischemia, and our studies demonstrated that SAA-deficient mice reduce inflammation and infarct volumes in a mouse stroke model. Our studies demonstrate that SAA increases the cytokine interleukin- $1 \beta$ (IL-1 $\beta$ ), which is mediated by Nod-like receptor protein 3 (NLRP3) inflammasome, cathepsin $B$, and caspase- 1 and may play a role in the pathogenesis of neurological disorders. SAA induced the expression of NLRP3, which mediated IL-1 $\beta$ induction in murine BV-2 cells and both sex primary mouse microglial cells, in a dose- and time-dependent fashion. Inhibition or KO of the NLRP3 in microglia prevented the increase in IL-1 $\beta$. $N$-acetyl-L-cysteine and mito-TEMPO blocked the induction of IL- $1 \beta$ by inhibiting ROS with SAA treatment. In addition, inhibition of cathepsin B with different drugs or microglia from CatBdeficient mice attenuated inflammasome activation. Our studies suggest that the impact of SAA on inflammasome stimulation is mediated in part by the receptor for advanced glycation endproducts and Toll-like receptor proteins 2 and 4. SAA induced inflammatory cytokines and an M1 phenotype in the microglial cells while downregulating anti-inflammation M2 phenotype. These studies suggest that brain injury to can elicit a systemic inflammatory response mediated through SAA that contributes to the pathological outcomes.

Key words: cathepsin B; inflammasome; inflammation; microglia; serum amyloid A

\section{Significance Statement}

In the present study, serum amyloid A can induce that activation of the inflammasome in microglial cells and give rise to IL- $1 \beta$ release, which can further inflammation in the brain following neurological diseases. The also presents a novel target for therapeutic approaches in stroke.

\section{Introduction}

Stroke is the third leading cause of death and the most frequent cause of permanent disability worldwide, and inflammation appears to play an important role in the pathogenesis of ischemic

Received April 9, 2019; revised July 9, 2019; accepted Sept. 3, 2019.

Author contributions: J.Y., H.Z., S.T., W.M., and M.S.K. performed research; J.Y., H.Z., S.T., and M.S.K. contributed unpublished reagents/analytic tools; J.Y., H.Z., S.T., W.M., L.B., G.S.M., D.L., R.J.A., and M.S.K. analyzed data; J.Y., H.Z., S.T., W.M., L.B., G.S.M., D.L., R.J.A., and M.S.K. edited the paper; L.B., G.S.M., D.L., R.J.A., and M.S.K. designed research; M.S.K. wrote the first draft of the paper; M.S.K. wrote the paper.

This work was supported in part by National Institutes of Health Grants R01 ES016774-01, R21AG043718, 1P20GM109091, 2P20GM103444, and 5P30GM103342, Veterans Administration Merit Award 101RX001450, National Science Foundation Grant IIP-0903795, and American Heart Association SFRN Grant 15SFDRN25710468 to M.S.K. M.S.K. is a Senior Research Career Scientist in the Veterans Administration.

The authors declare no competing financial interests.

Correspondence should be addressed to Mark S. Kindy at kindym@health.usf.edu.

https://doi.org/10.1523/JNEUROSCI.0801-19.2019

Copyright $\odot 2019$ the authors stroke and other forms of ischemic brain injury (Donnan et al., 2008). In the clinical setting, the vulnerability of the patients to stroke and the ensuing prognosis are influenced by inflammation in the systemic circulation (Emsley and Hopkins, 2008; McColl et al., 2009). Stroke patients with systemic inflammation demonstrate poorer outcomes clinically (Baird et al., 2002; Elkind et al., 2004; McColl et al., 2007). In experimental models, focal cerebral ischemia provokes a time-dependent recruitment and subsequent activation of inflammatory cells, which include neutrophils, T cells, and monocytes/macrophages, and inhibition of the inflammatory process can reduce infarct size and improve neurological deficits (Wang, 2005; Yilmaz and Granger, 2008). A multitude of animal models studies have shown that antiinflammatory approaches are successful; however, translational advances have been unsuccessful and failed due to the heterogeneity in the mechanisms that are involved in brain inflammation and the complex interaction between beneficial and detrimental 
inflammation (Zhang et al., 1995, 2003; Prestigiacomo et al., 1999; Enlimomab Acute Stroke Trial Investigators, 2001; Becker, 2002). Therefore, a better understanding of how inflammatory cells are recruited following stroke, how these cells contribute to ischemic brain injury, and the role of systemic inflammatory factors in stroke outcomes is a necessary to develop successful therapeutic interventions for the treatment of stroke.

Inflammation is part of the immune response pathway, which has the ability to perceive specific tissue damage and infection. The innate immune responses appear to be the first line of defense against specific pathogens (Herman and Pasinetti, 2018; Herman et al., 2019). This process responds to certain conserved characteristics not normally seen in the host. In the brain, the microglial cells are the "primary mediators" that respond and proliferate in the presence of foreign entities. Via "priming" and "activation" steps, the microglia are triggered to different phenotypic states that will determine the response to the pathogen or injury. These detrimental processes can be sensed at the inception and progression of stroke by activating a number of pattern recognition receptors, which include Toll-like receptors (TLRs), RIG-I-like receptors, and NOD-like receptors (NLRs), all of which are cytosolic sensors or receptors (Ye and Ting, 2008). The NLRs have been identified as crucial constituents of the inflammasome, and the inflammasomes are comprised of a multiprotein complex by the activation of NLRs. The inflammasome complex involves a number of members that include the following: Nod-like receptor protein 1 (NLRP1), NLRP3, NLRC4, NLRC5, NLRP6, NLRP7, NLRP12, NLRC4, and AIM2 (Pedra et al., 2009). The NLRP3 inflammasome is probably the most broadly examined and has the closest link to sterile inflammation. However, the mechanisms associated with how the NLRP3 is activated remains elusive. The NLR proteins encompass three specific domains: a C-terminal leucine-rich repeat domain, a central nucleotide binding (NACHT) domain, and an $\mathrm{N}$-terminal pyrin domain (PYD) (Martinon and Tschopp, 2007). The ligands interact with leucine-rich repeat regions and regulate their own inhibition, and the NACHT domain mediates oligomerization and assembly of the inflammasome (Duncan et al., 2007; Lamkanfi and Dixit, 2009).

Activation of the NLRP3 inflammasome occurs via a number of danger-associated molecular patterns and pathogenassociated molecular patterns. Upon signal activation, formation of the NLRP3 inflammasome begins, which is the assembly of the NLRP3, an adaptor protein ASC (apoptosis-associated speck-like protein containing a caspase activation and recruitment domain), and pro-caspase-1. Recent studies have demonstrated that the leucine-rich repeats can regulate the function of the NLRP3 by preventing oligomerization under normal cellular environments (Latz et al., 2013). However, when activated, the NLRP3 can oligomerize via the NACHT domains. Next, association of the ASC proteins into fiber-like structures that cooperate with PYD, thus recruiting pro-caspase-1, giving rise to activated caspase-1 (Garg, 2011; Gross et al., 2011; Schmidt et al., 2016). Studies have implicated a reduction in intracellular $\mathrm{K}^{+}$concentrations, generation of mitochondrial ROS, and disruption of the lysosomal membranes, and release of cathepsin B can stimulate the NLRP3 inflammasome (Martinon et al., 2002; Lamkanfi et al., 2009).

Serum amyloid A (SAA) proteins are highly conserved acutephase proteins, which are stimulated in response to inflammation or infection. The production of acute-phase SAA (A-SAA, SAA1.1, and SAA2.1) is triggered by proinflammatory cytokines, such as interleukin-6 (IL-6), IL- $1 \beta$, TNF- $\alpha$, interferon- $\gamma$, and
TGF- $\beta$. The normal concentration of A-SAAs is $\sim 1-5 \mu \mathrm{g} / \mathrm{ml}$, and the levels increase dramatically during acute inflammation and injury, reaching $>1 \mathrm{mg} / \mathrm{ml}$ within $6-8 \mathrm{~h}$ (Migita et al., 2011; Nakamura, 2011; Cai et al., 2014). The liver is the primary source of plasma SAA, yet the production of SAA by several other tissues and cell types has been described; this includes Alzheimer's disease, various cancers, in diabetes, obesity, insulin resistance, metabolic syndrome, and atherosclerosis (Yang et al., 2006; Targonska-Stepniak et al., 2010; Wang and Nakayama, 2010). SAA proteins have been referred to as adipokine in nature due to the relationship with inflammation and obesity (Connolly et al., 2012). In addition, a number of studies have implicated SAAs in various pathological roles as the proinflammatory cascade in the course of rheumatoid arthritis (Xie et al., 2010). SAAs are apolipoproteins (apo) and play an important role in cholesterol metabolism, by altering high-density lipoprotein (HDL) protein content. During inflammation, SAA levels increase and displace apoA-I as the major protein constituent of the HDL, accounting for $\sim 80 \%$ of the total apolipoprotein content. This impairs the anti-inflammatory nature of the HDL particle, becoming more proinflammatory, and can increase the oxidation of low-density lipoprotein (LDL) and thus may be associated with cardiovascular disease and atherosclerosis (Connolly et al., 2012; Shridas et al., 2018).

Recent studies have demonstrated that, following brain injury, SAA levels are dramatically increased in the plasma and may contribute to the disease process (Brea et al., 2009). In addition, activation of the inflammasome has been implicated in the development and progression of these disorders (Gao et al., 2017). To better understand the impact of SAA on microglial function, we determined the effect of SAA on inflammasome activation of microglial cells. We found that SAA activated the NLRP3 inflammasome via the production of ROS, release and activation of cathepsin B from the lysosomes, and partially mediated by alteration in potassium levels. These results demonstrate that SAA may be critical in the response of the brain to the pathological effects of stroke conceptualized in the context of systemic inflammation.

\section{Materials and Methods}

Animals. Mice deficient in both SAAs, NLRP3, cathepsin B, cathepsin L, receptor for advanced glycation endproducts (RAGE), TLR2/4, and RAGE/TLR2/4 were provided by various sources as described previously (Arancio et al., 2004; de Beer et al., 2010; Hook et al., 2014). C57BL/6 mice were purchased from The Jackson Laboratory. Animals were bred and as described below; 7- to 9-week-old male and female animals were used, and microglial cells were isolated and used in culture (Keller et al., 1999). Institutional Animal Care and Use Committee protocols were approved by University of South Florida.

HDL isolation. Acute-phase HDL particles (density $=1.063-1.21$ ) were isolated from C57BL/6, SAA1.1 KO, and SAA2.1 KO mice and humans by density gradient ultracentrifugation, dialyzed against $150 \mathrm{mM}$ $\mathrm{NaCl}, 0.01 \%$ EDTA, sterile filtered, and stored at $4^{\circ} \mathrm{C}$ (Webb et al., 2002).

Purification and use of SAA. Mouse SAA (mSAA) and human SAA (hSAA) were purified as previously described (Liao et al., 1994). mSAA was isolated from HDL as described above $24 \mathrm{~h}$ after mice were injected with $100 \mu \mathrm{g} /$ mouse of lipopolysaccharide (LPS). The HDL fractions were delipidated, and the proteins were separated by gel filtration on Sephacryl S-200 columns in buffer containing $7 \mathrm{~m}$ urea, $20 \mathrm{~mm}$ Tris, $150 \mathrm{~mm} \mathrm{NaCl}$, and $1 \mathrm{~mm}$ EDTA, $\mathrm{pH}$ 8.0. The SAA was determined by SDS-PAGE, and the fractions pooled and dialyzed with $2 \mathrm{~mm}$ Tris, $15 \mathrm{~mm} \mathrm{NaCl}$, and 0.1 mM EDTA, $\mathrm{pH}$ 8.4, and then concentrated using centrifugation filters (EMD Millipore Amicon). The proteins were sterile filtered with $0.22 \mathrm{mM}$ filters and stored at $4^{\circ} \mathrm{C}$. mSAA was a mixture of SAA1.1, SAA2.1, and SAA3 (limited) for the studies. 
Cell culture and treatments. Murine BV-2 microglial cells, an immortalized mouse microglial cell line, was a kind gift from Dr. Dennis Selkoe (Harvard University). The cells were cultured in RPMI 1640 medium supplemented with $10 \%$ fetal bovine serum (FBS) and antibioticantimycotic mixture. Stock cultures maintained in $100 \mathrm{~mm}$ dishes were subcultured as needed into 6-well and 24-well plates. HMC3 human microglial cells were obtained from ATCC and grown in Earle's modified Eagles medium (EMEM) with 10\% FBS.

Induction of ischemia. The mice were anesthetized with isoflurane ( $1 \%-2 \%$ in $70 \% / 30 \% \mathrm{NO}_{2} / \mathrm{O}_{2}$ by mask) (Yu et al., 2016). Measurement of mean arterial blood pressure occurred via tail cuff apparatus. The mean arterial blood pressure and heart rate were recorded using a blood pressure monitor (Visitech System). Brain temperature was monitored using a rectal thermometer, and thermistor probe inserted into the temporalis muscle. The animals' body temperature was preserved at $37 \pm$ $0.3^{\circ} \mathrm{C}$ by using water-jacketed heating pads. The temperature of the brain was monitored for $1 \mathrm{~h}$ before ischemia to $6 \mathrm{~h}$ following the start of reperfusion. After the start of anesthesia, and the external carotid artery (ECA) and common carotid artery (CCA) were sequestered. The left CCA was exposed through a midline incision in the neck. The superior thyroid and occipital arteries were electrocoagulated and divided. A microsurgical clip was placed around the origin of the ECA. The distal end of the ECA was ligated with 6-0 silk and transected. A 6-0 silk was tied loosely around the ECA stump. After the clip was removed, the firepolished tip of a 5-0 nylon suture (silicone coated) was gently inserted into the ECA stump. The loop of the 6-0 silk was tightened around the stump, and the nylon suture was advanced $\sim 13 \mathrm{~mm}$ (adjusted for body weight) into and through the internal carotid artery until it rested in the anterior cerebral artery, thereby occluding the anterior communicating and middle cerebral arteries. After the nylon suture was in place for $1 \mathrm{~h}$, it was pulled back into the ECA and the incision closed.

Histological examination. For histological analyses, the animals were anesthetized with an intraperitoneal injection of sodium pentobarbital $(50 \mathrm{mg} / \mathrm{kg})$ at the indicated times of reperfusion after ischemia was induced. The brains were transcardially perfused with $4^{\circ} \mathrm{C}, 10 \% \mathrm{PBS}$. The brains were removed and chilled for $15 \mathrm{~min}$ at $-20^{\circ} \mathrm{C}$ before being placed in a Rodent Brain Matrix. Coronal sections ( $1 \mathrm{~mm}$ thickness) were prepared and subjected to $2 \%$ triphenyltetrazolium chloride staining at $37^{\circ} \mathrm{C}$. The triphenyltetrazolium chloride stains live tissue (red) versus dead or dying tissue (white). Seven serial 1-mm-thick coronal sections through the rostral to caudal extent of the infarction were obtained from each brain, beginning $2 \mathrm{~mm}$ from the frontal pole. The triphenyltetrazolium chloride-stained sections were placed in $10 \%$ neutral-buffered formalin and kept in darkness at $4^{\circ} \mathrm{C}$ for at least $24 \mathrm{~h}$. The infarct area in each section was determined with a computer-assisted image analysis system, consisting of a Power Macintosh computer equipped with a Quick Capture frame grabber card, Hitachi CCD camera mounted on an Olympus microscope, and camera stand. National Institutes of Health's ImageJ analysis software (version 1.55) was used. The images were captured, and the total area of damage determined over the seven sections. A single operator blinded to treatment status performed all measurements. The infarct volume was calculated by summing the infarct volumes of the sections. Infarct size (\%) was calculated by using the following formula: (contralateral volume - ipsilateral undamaged volume) $\times 100 /$ contralateral volume to eliminate effects of edema.

Behavioral assessment. Behavioral analyses (neurological deficit) were determined in the mice before and after ischemic injury. Neurological scores were as follows: 0 , normal motor function; 1 , flexion of torso and contralateral forelimb when the animal was lifted by the tail; 2 , circling to the contralateral side when held by tail on flat surface, but normal posture at rest; 3 , leaning to the contralateral side at rest; and 4, no spontaneous motor activity.

Isolation and treatment of primary microglial cells. All of the following isolation and purification steps were performed by using a sterile PBS $\left(8 \mathrm{~g} / \mathrm{L} \mathrm{NaCl}, 0.4 \mathrm{~g} / \mathrm{L} \mathrm{KCl}, 3.56 \mathrm{~g} / \mathrm{L} \quad \mathrm{Na}_{2} \mathrm{HPO}_{4} \cdot 12 \mathrm{H}_{2} \mathrm{O}, 0.78 \mathrm{~g} / \mathrm{L}\right.$ $\mathrm{NaH}_{2} \mathrm{PO}_{4} \cdot 2 \mathrm{H}_{2} \mathrm{O}$, and $2 \mathrm{~g} / \mathrm{L} \mathrm{D}-(+)$-glucose, $\mathrm{pH}$ 7.4). Animals were killed by $\mathrm{CO}_{2}$ asphyxiation, then perfused slowly via the ascending aorta with $200-250 \mathrm{ml}$ of cold PBS containing $2 \mathrm{U} / \mathrm{ml}$ heparin (Sigma-Aldrich), at an approximate hydrostatic pressure of $1 \mathrm{~m}$ of water. After perfusion of the circulatory system, the brain and spinal cord were removed into ice-cold PBS containing $0.02 \%(\mathrm{w} / \mathrm{v})$ isotonic BSA and mechanically dissociated through a stainless-steel sieve. The dissociated CNS material was collected into one $50 \mathrm{ml}$ centrifuge tube and washed by centrifugation at $400 \times g$ for $10 \mathrm{~min}$. Supernatant was removed, and the preparation was enzymatically digested for $60 \mathrm{~min}$ at $37^{\circ} \mathrm{C}$ by addition to the slurry of 5-15 U Type II collagenase (Sigma-Aldrich) and 500 U DNase I (Sigma-Aldrich). The enzymes were resuspended in enzyme buffer $(4.00$ $\mathrm{g} / \mathrm{L} \mathrm{MgCl}_{2}, 2.55 \mathrm{~g} / \mathrm{L} \mathrm{CaCl}_{2}, 3.73 \mathrm{~g} / \mathrm{L} \mathrm{KCl}$, and $8.95 \mathrm{~g} / \mathrm{L} \mathrm{NaCl}$, pH 6-7). During the course of the digestion, the preparation was gently resuspended twice. The preparation was washed twice with $40 \mathrm{ml}$ PBS/BSA and pelleted by centrifugation. After removing supernatant, the material was resuspended in $\sim 20 \mathrm{ml}$ of isotonic Percoll, diluted in PBS/BSA to a density (p) of $1.03 \mathrm{~g} / \mathrm{ml}$. This was underlayered with $10 \mathrm{ml}$ of Percoll ( $\mathrm{p}$ ) of 1.095 and overlaid with $10 \mathrm{ml}$ PBS/BSA. This initial gradient was centrifuged at $1250 \times \mathrm{g}$ for $30 \mathrm{~min}$ at $20^{\circ} \mathrm{C}$. The cells were collected from the top of the $1.095 \mathrm{~g} / \mathrm{ml}$ layer after discarding the myelin debris on top of the $\mathrm{p}=1.03$ layer. After washing once with $50 \mathrm{ml}$ PBS/BSA and centrifugation $(400 \times g ; 10 \mathrm{~min})$, the cell pellet was resuspended in $2 \mathrm{ml} \mathrm{PBS} /$ BSA and layered onto the top of the second gradient. This consisted of 2 $\mathrm{ml}$ steps of isotonic (p, $1.12 \mathrm{~g} / \mathrm{ml}), 1.088 \mathrm{~g} / \mathrm{ml}, 1.072 \mathrm{~g} / \mathrm{ml}$, and $1.03 \mathrm{~g} / \mathrm{ml}$ Percoll. This gradient was centrifuged at $1250 \times g$ for $20 \mathrm{~min}$ at $20^{\circ} \mathrm{C}$. Cells were collected from the $1.072 \mathrm{~g} / \mathrm{ml}$ and $1.088 \mathrm{~g} / \mathrm{ml}$ interfaces. After washing the cells in PBS/BSA, their viability was determined immediately by trypan blue.

Isolation of RNA and qRT-PCR analysis. Total RNA was isolated from cultured cells according to the manufacturer's instructions (RNeasy MiniKit, QIAGEN). RNA samples were incubated with DNase I (QIAGEN) for $15 \mathrm{~min}$ at room temperature before reverse transcription. RNA from cultured cells $(0.2-0.5 \mu \mathrm{g})$ was reverse-transcribed into cDNA using the Reverse Transcription System (Applied Biosystems). After fourfold dilution, $5 \mu \mathrm{l}$ was used as a template for real-time RT-PCR. Amplification was done for 40 cycles using Power SYBR Green PCR Mastermix kit (Applied Biosystems). Quantification of mRNA was performed using the ddCT method and normalized to GAPDH. Primer sequences are as follows: GAPDH (NM_008084)， 5'-CTCATGACCACAGTCCATGCCA-3'， 5' GGATGACCTTGCCCACAGCCTT-3'; IL-1 $\beta$ (NM_008361), 5'-GTCAC AAGAAACCATGGC ACAT-3', 5'GCCCATCAGAGGCAAGGA-3'; and NLRP3 (XR_388400), 5' -TGCTCTTCACT GCTATCAAGCCCT-3', 5' ACAAGCCTTTGCTCCAGACCCTAT- ${ }^{\prime}$.

Western blot analysis. Cell lysates containing equal amounts of protein were electrophoresed on 4\%-20\% SDS-polyacrylamide gels and transferred to PVDF membranes. The membranes were blocked with 5\% BSA in TBST (20 mM Tris, pH 7.5, $137 \mathrm{~mm} \mathrm{NaCl}, 0.1 \%$ Tween 20) and incubated with TBST-1\% BSA containing primary antibodies (p49/p20, NLRP3, cathepsin B, $\beta$-actin, Arg- 1 from Abcam) at appropriate dilutions. After washing 3 times with TBST for 5 min each, membranes were incubated in secondary antibodies conjugated to HRP at dilutions of 1:10,000 in TBST-1\% BSA. Membranes were washed 4 times in TBST for 5 min each before the detection of the bands using enhanced chemiluminescence (Pierce).

$S A A$ and cytokine assays. Spent medium from experimental cultures was harvested at the indicated times after different treatments and used for ELISAs. Aliquots of samples determined to be within the linear range of detection were incubated in 96-well plates at $4^{\circ} \mathrm{C}$ overnight, wells were washed with PBS-T, followed by the addition of the primary antibody (in $50 \mu \mathrm{l}$ volume), and incubated for $2 \mathrm{~h}$ at room temperature. Wells were washed again and incubated for $1 \mathrm{~h}$ at room temperature with biotinylated secondary per milliliter. After another round of washing, a 1:1000 dilution of avidin-HRP was added to each well and incubated for $30 \mathrm{~min}$ at room temperature, and wells were washed and incubated with $3,3^{\prime}, 5,5^{\prime}$-tetramethylbenzidine for $8-10 \mathrm{~min}$. Samples were read at 630 $\mathrm{nm}$ using microplate reader. The protein concentration was estimated against recombinant mouse standards (IL- $1 \beta$, IL- 18 , TNF- $\alpha$, IL- 6 from R\&D Systems).

2,7-Dichlorofluorescin (DCF) fluorescence analysis. For determinations of ROS formation, cells were exposed to the fluorescent ROS indicator DCF (Invitrogen). Cell cultures were plated onto 24-well plates and treated with various reagents for the times indicated. During the last 30 

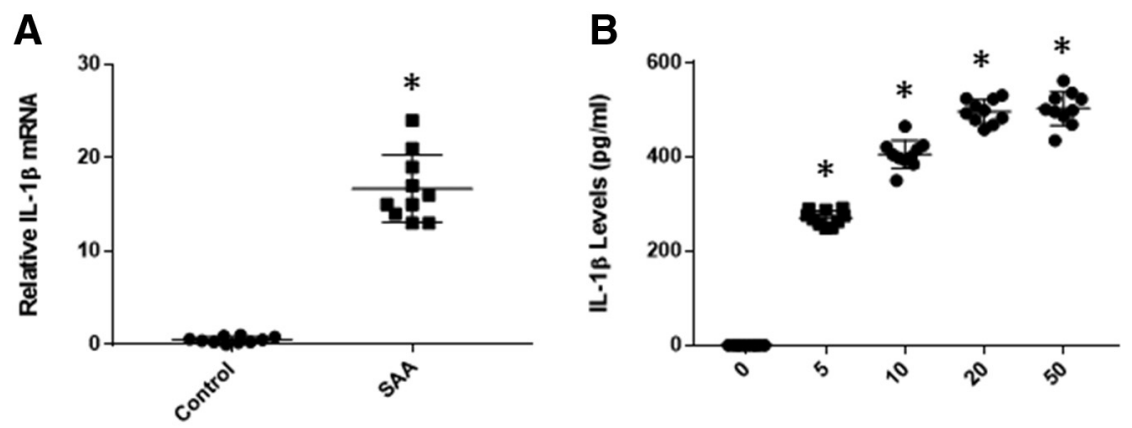

SAA concentration $(\mu \mathrm{g} / \mathrm{ml})$

E
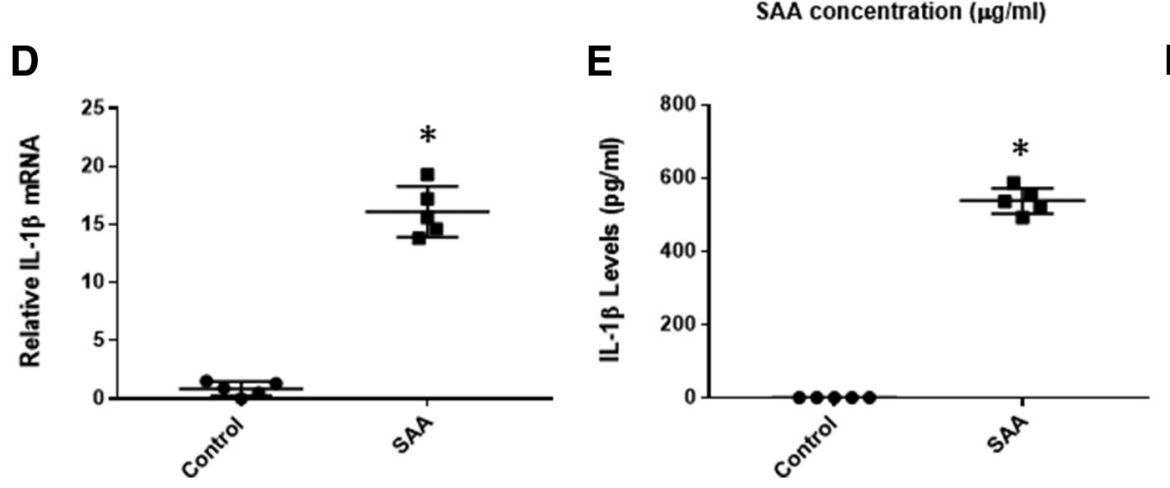

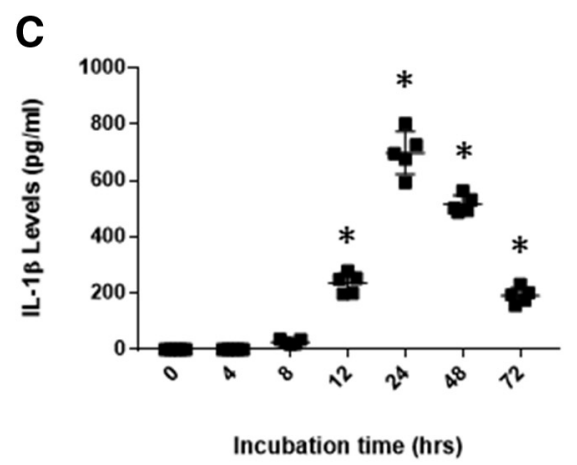

$\mathbf{F}$

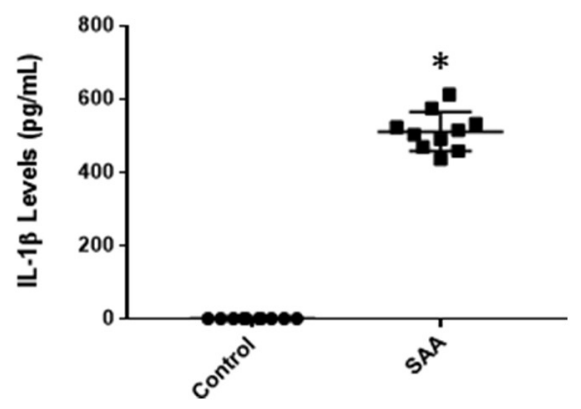

Figure 1. SAA stimulates inflammasome activation in microglial cells. $A, B V-2$ cells were incubated with $50 \mu \mathrm{g} / \mathrm{ml}$ of $\mathrm{mSAA}$ for $12 \mathrm{~h}$ before quantification of IL-1 $\beta \mathrm{mRNA}$ by qRT-PCR. $\boldsymbol{B}, \mathrm{BV}-2$ cells were incubated with the indicated concentrations of mSAA for $24 \mathrm{~h}$, and IL- $1 \beta$ levels were determined by ELISA. C, BV- 2 cells were incubated with $10 \mu \mathrm{g} / \mathrm{ml}$ of $\mathrm{mSAA}$ for the indicated times, and IL- $1 \beta$ was assayed in the media by ELISA. D, Primary mouse microglial cells were incubated with $25 \mu \mathrm{g} / \mathrm{ml}$ of mSAA for $8 \mathrm{~h}$ and assayed for IL- $1 \beta$ mRNA levels by qRT-PCR. E, Primary mouse microglial cells were incubated with $25 \mu \mathrm{g} / \mathrm{ml}$ of mSAA and the amount of IL- $1 \beta$ in the media determined by ELISA. $F$, MHC 3 human microglial cells were incubated with $25 \mu \mathrm{g} / \mathrm{ml} \mathrm{hSAA}$ and the level of IL-1 $\beta$ determined by ELISA in the media. Data are mean \pm SE. The measurements are from 8 to 10 repeats per treatment. ${ }^{*} p<0.001$ compared with control. Data are considered significantly different at $p<0.05$.

min of treatment, DCF was added $(10 \mu \mathrm{M})$ to cultures. Following incubation with DCF, cultures were washed three times with Locke's solution and the fluorescence measured using a FLUOstar Optima plate reader (BMG) as described previously (Webb et al., 2002).

Statistical analysis. Experiments were performed a minimum of three times. The data (mean \pm SEM) were analyzed using ANOVA followed by post hoc test.

\section{Results}

mSAA and hSAA induce IL-1 $\beta$ expression and secretion in microglial cells

Previous studies have shown that SAA is induced in response to various neurological injuries, such as cerebral ischemia and traumatic brain injury (TBI), suggesting that SAA may play a role in regulation of inflammation. To help understand the role of SAA in the control of IL- $1 \beta$ production in the brain following injury, BV-2 mouse microglial cells were treated with purified mSAA proteins at $50 \mu \mathrm{g} / \mathrm{ml}$ for $12 \mathrm{~h}$ showed a significant increase in IL- $1 \beta$ mRNA as well as protein secreted into the media (Fig. $1 A, B$ ). We also showed that SAA induced a dose-response and time-dependent expression of IL- $1 \beta$ in the BV-2 cells (Fig. $1 B, C$ ). We also validated that these changes were seen in pri-
A

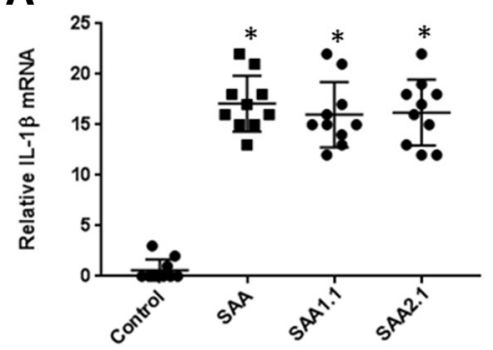

C

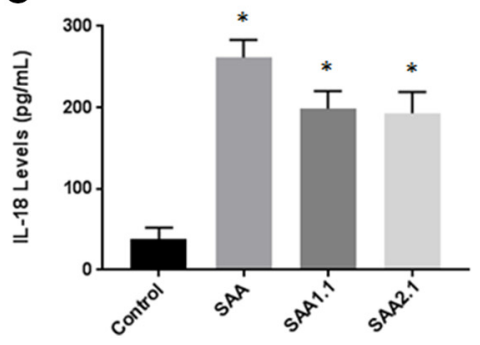

B

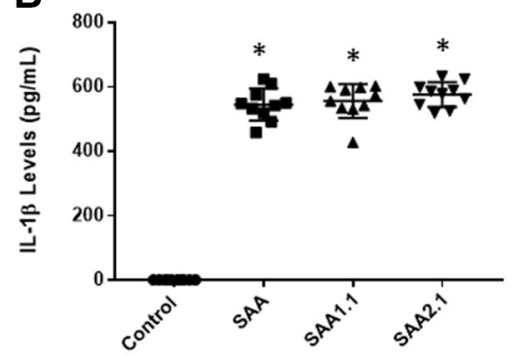

D

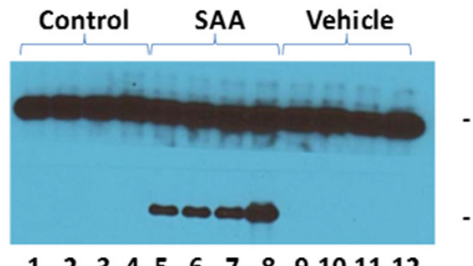

P49

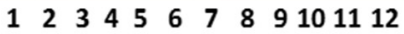

Figure 2. Impact of mSAA isoforms on inflammasome activation in BV2 microglial cells. $A, B V-2$ cells were incubated with 25 $\mu \mathrm{g} / \mathrm{ml}$ of mouse total SAA, SAA1.1, or SAA2.1 for $12 \mathrm{~h}$ before quantification of IL-1 $\beta$ mRNA by qRT-PCR. B, BV-2 cells were incubated with $10 \mu \mathrm{g} / \mathrm{ml}$ of mouse total SAA, SAA1.1, or SAA2.1 for the indicated times and IL-1 $\beta$ was assayed in the media by ELISA. C, BV-2 cells were incubated with $10 \mu \mathrm{g} / \mathrm{ml}$ of mouse total SAA, SAA1.1, or SAA2.1 for the indicated times, and IL-18 was assayed in the media by ELISA. D, BV-2 cells were incubated with $10 \mu \mathrm{g} / \mathrm{ml}$ of $\mathrm{mSAA}$ for $24 \mathrm{~h}$, and activation of caspase-1 was determined by immunoblot analysis; the migration of procaspase-1 (p49) and the active capase-1 (p20) cleavage product is indicated. Data are mean \pm SE. The measurements are from 8 to 10 repeats per treatment. ${ }^{*} p<0.001$ compared with control. Data are considered significantly different at $p<0.05$. 
A

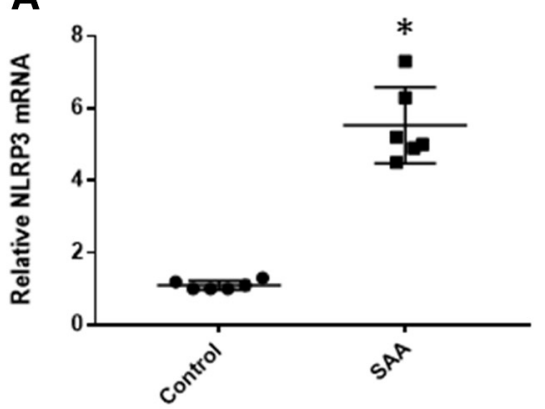

D

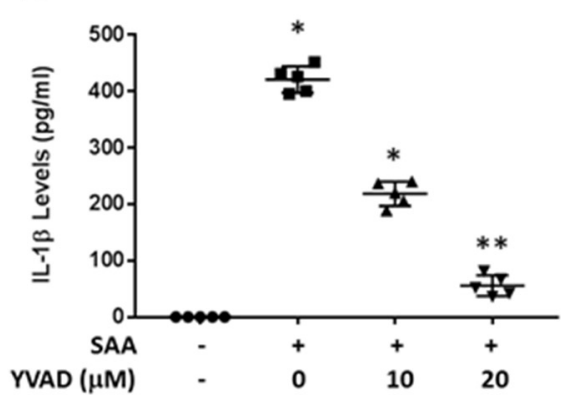

B

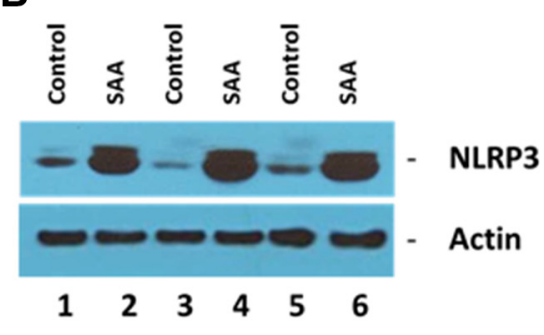

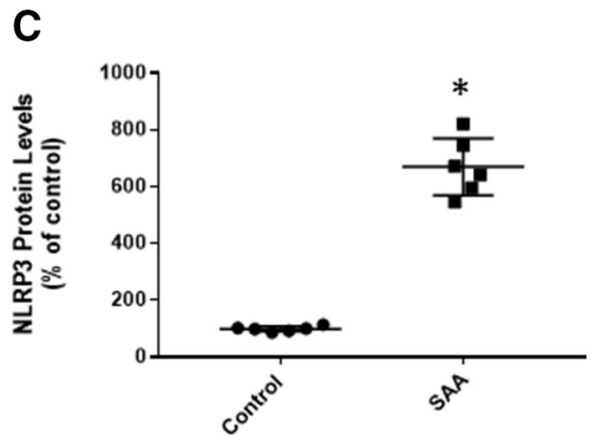

$\mathbf{F}$
E

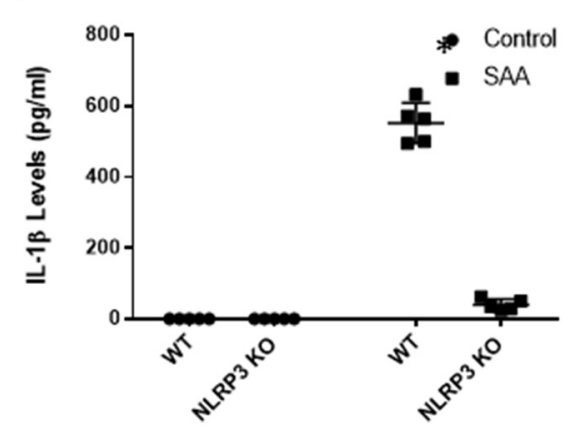

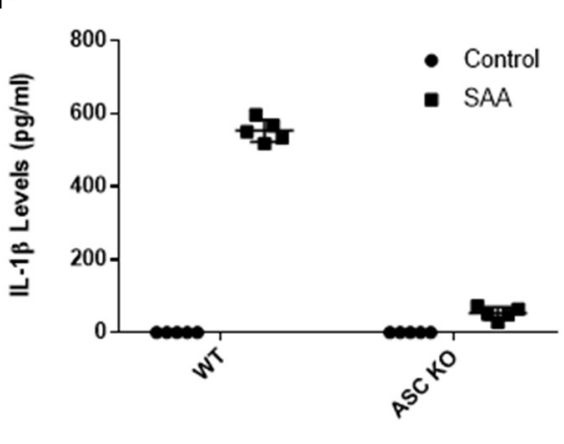

Figure 3. SAA stimulates NLRP3 inflammasome activation and IL-1 $\beta$ generation in microglia. $A, B V-2$ cells were incubated with $50 \mu g / m l$ of $\mathrm{mSAA}$ for $12 \mathrm{~h}$, and RNA was isolated for quantification of NLRP3 mRNA by qRT-PCR. B, BV-2 cells were incubated with $50 \mu \mathrm{g} / \mathrm{ml}$ of $\mathrm{mSAA}$ for $24 \mathrm{~h}$, and NLRP3 protein levels were determined by Western blot analysis. C, Quantification of Western blots generated in $\boldsymbol{B}$. D, IL-1 $\beta$ levels were determined in BV-2 cells incubated with $10 \mu \mathrm{g} / \mathrm{ml}$ of mSAA with and without the addition of YVAD (caspase-1 specific inhibitor) at the indicated concentrations. $\boldsymbol{E}$, IL-1 $\beta$ levels assayed in the media from primary microglial cells from WT and NLRP3-deficient mice in the presence and absence of $\mathrm{mSAA}$ at $10 \mu \mathrm{g} / \mathrm{ml}$ for $24 \mathrm{~h}$. $\boldsymbol{F}$, IL- $1 \beta$ levels assayed in the media from primary microglial cells from WT and ASC-deficient mice in the presence and absence of mSAA at $10 \mu \mathrm{g} / \mathrm{ml}$ for $24 \mathrm{~h}$. Data are mean \pm SE. The measurements are from 8 to 10 repeats per treatment. ${ }^{*} p<0.001$ compared with control. ${ }^{* *} p<0.01$ compared to control. Data are considered significantly different at $p<0.05$.

mary mouse microglial cells isolated from the brains for C57BL/6 mice (Fig. $1 D, E$ ). To validate that these changes occur in humans, we used a human microglial cell line (HMC3) and hSAA to show that IL- $1 \beta$ was induced in the cells in a similar manner as with the mouse cells (Fig. $1 F$ ).

\section{SAA isoforms all activate the NLRP3 inflammasome}

To determine the impact of the individual mSAA isoforms on activation of the NLRP3 inflammasome, SAA1.1 and SAA2.1 were isolated from the appropriate SAA KO mice (de Beer et al., 2010; Kim et al., 2013). In Figure $2 A, B$, with specific SAA isoforms isolated from SAA1.1 and SAA2.1 KO mice, we treated the BV-2 microglial cells with $25 \mathrm{mg} / \mathrm{ml}$ of each SAA and examined the cells for expression and secretion of IL-1 $\beta$. As seen in the figure, both $S A A 1.1$ and $S A A 2.1$ were capable of inducing IL- $1 \beta$. SAA proteins also increased IL-18 levels in the BV-2 microglial cells (Fig. 2C). These data suggest that there are no differences in the SAA isoforms in activation of the inflammasome.

\section{SAA stimulates NLRP3 inflammasome activation and IL-1 $\beta$ generation in microglia}

Since IL- $1 \beta$ expression is mediated by the NLRP3 inflammasome, we determined the impact of SAA on activation. Treatment of BV-2 microglial cells with $50 \mu \mathrm{g} / \mathrm{ml}$ of SAA for $12 \mathrm{~h}$ elicited a fivefold increase in NLRP3 mRNA expression (Fig. 3A). Western blot analysis showed that SAA increased the protein expression of NLRP3 in the BV-2 cells, which is consistent with the mRNA data (Fig. $3 B, C$ ). Activation of NLRP3 leads to the cleavage of procaspase- 1 to caspase- 1 , which results in the cleavage of pro-IL- $1 \beta$ and pro-IL-18 to IL- $1 \beta$ and IL-18 (Latz et al., 2013). As seen in Figure $2 B$, the "activation" step of the inflam- masome complex involves the intracellular assembly, which results in the activation of caspase-1. Western blot analysis demonstrated an increase in the p20 fragment of caspase- 1 when incubated with $20 \mu \mathrm{g} / \mathrm{ml}$ of mSAA for $24 \mathrm{~h}$. To further validate the impact of SAA on NLRP3 activation and subsequent production of IL-1 $\beta$, primary microglial cells isolated from WT (C57BL/6) mice were treated with $50 \mu \mathrm{g} / \mathrm{ml}$ of mSAA in the absence or presence of YVAD (caspase-1 specific inhibitor) at different concentrations (Fig. 3D). As seen in the figure, mSAA increased IL- $1 \beta$ levels in the microglia, and YVAD was able to block IL- $1 \beta$ release in a dose-dependent fashion. Additionally, we isolated microglial cells from NLRP3-deficient mice (Latz et al., 2013) and compared them with the WT mice for elaboration of IL- $1 \beta$ (Fig. $3 E$ ). As seen in the figure, IL- $1 \beta$ is increased in the WT mice, whereas the NLRP3-deficient mice have attenuated IL- $1 \beta$ expression. Additionally, the inflammasome complex requires the recruitment of ASC in order for activation to occur (Latz et al., 2013). Using microglial cells isolated from ASCdeficient mice, we were able to show that the SAA-mediated increase in IL- $1 \beta$ was inhibited in the cells (Fig. $3 F$ ). Since the IL- $1 \beta$ is significantly reduced in the NLRP3-deficient mice microglia, we can say with reasonable certainty that SAA stimulates IL-1 $\beta$ through the inflammasome complex (Shridas et al., 2018).

\section{SAA impacts outcomes from cerebral ischemia and} reperfusion injury in the mouse

To put into perspective the impact of SAA in an animal model of cerebral ischemia and reperfusion injury, SAA double $\mathrm{KO}$ (SAADKO) mice subjected to $1 \mathrm{~h}$ ischemia and $24 \mathrm{~h}$ or $7 \mathrm{~d}$ of reperfusion showed not only a reduction in the total infarct volume [63.35 $\pm 4.017 \mathrm{~mm}^{3}$ (WT) compared with $35.83 \pm 2.641$ 
$\left.\mathrm{mm}^{3}(S A A D K O)\right]$, but a decrease in the infarct volume over time (see $24 \mathrm{~h}$ to $7 \mathrm{~d}$ in each of the groups) (Fig. $4 A$ ). Furthermore, the SAADKO mice showed a significant reduction in IL- $1 \beta$ levels in the brain following ischemia and reperfusion injury (Fig. 4B). The Neurological Severity Score was also reduced (or was not increased) as seen in the WT mice (Fig. 4C).

SAA-mediated activation of the inflammasome requires $\mathrm{K}^{+}$efflux and not P2X7R activation

Previous studies have implicated potassium $\left(\mathrm{K}^{+}\right)$in the activation of the NLRP3 inflammasome, and a recent study showed that SAA could function through this mechanism in monocytes/macrophages (Shridas et al., 2018). To determine whether microglia function in the same fashion as macrophages, we treated BV-2 cells with $10 \mu \mathrm{g} / \mathrm{ml}$ of mSAA in the presence or absence of glyburide at $200 \mu \mathrm{M}$ or in the presence of $20 \mathrm{mM} \mathrm{K}^{+}$(Fig. 5A). As shown in the figure, SAA induced IL- $1 \beta$ secretion, whereas glyburide inhibited the increase in IL- $1 \beta$. In addition, the presence of increased extracellular $\mathrm{K}^{+}$levels also inhibited the SAA increase in IL- $1 \beta$, suggesting that the SAA-mediated NLRP3 induction is regulated by $\mathrm{K}^{+}$efflux. Studies have shown that the $\mathrm{K}^{+}$efflux is mediated by the $\mathrm{P} 2 \mathrm{X} 7$ receptor via an ATP-mediated mechanism and that SAA in macrophages did not use this pathway in the $\mathrm{K}^{+}$-mediated increase in inflammasome activation and IL- $1 \beta$ release (Shridas et al., 2018). To determine the impact of the P2X7 receptor on SAAmediated inflammasome activation and IL- $1 \beta$ production, BV -2 cells were treated with a $\mathrm{P} 2 \mathrm{X} 7 \mathrm{r}$-specific negative allosteric modulator (AZ10606120) or a P2X7rspecific antagonist (A438079) (Fig. 5B). As seen in the figure, neither the negative allosteric modulator $(10 \mu \mathrm{M})$ nor the antagonist $(25 \mu \mathrm{M})$ was able to block the induction of IL- $1 \beta$ in the microglial cells.

\section{SAA instigates ROS production in microglial cells, and blocking ROS attenuates IL-1 $\beta$ production}

Oxidative stress is implicated in neuronal apoptosis that occurs in physiological settings and in neurodegenerative disorders. ROS are generated during ischemia and reperfusion injury that may contribute to the disease progression. In addition, studies have shown that ROS contribute to the activation of the inflammasome complexes mediating cytokine production (Bauer et al., 2010). To determine the impact of SAA on the production of ROS and the subsequent activation of the NLRP3 inflammasome, $\mathrm{BV}-2$ cells were treated with $10 \mu \mathrm{g} / \mathrm{ml}$ of $\mathrm{mSAA}$, and the generation of ROS was calculated by DCF fluorescence (Fig. 6A). As seen in the figure, addition of the SAA to the culture media resulted in a 2.5-fold increase in DCF fluorescence compared with control different at $p<0.05$.
B
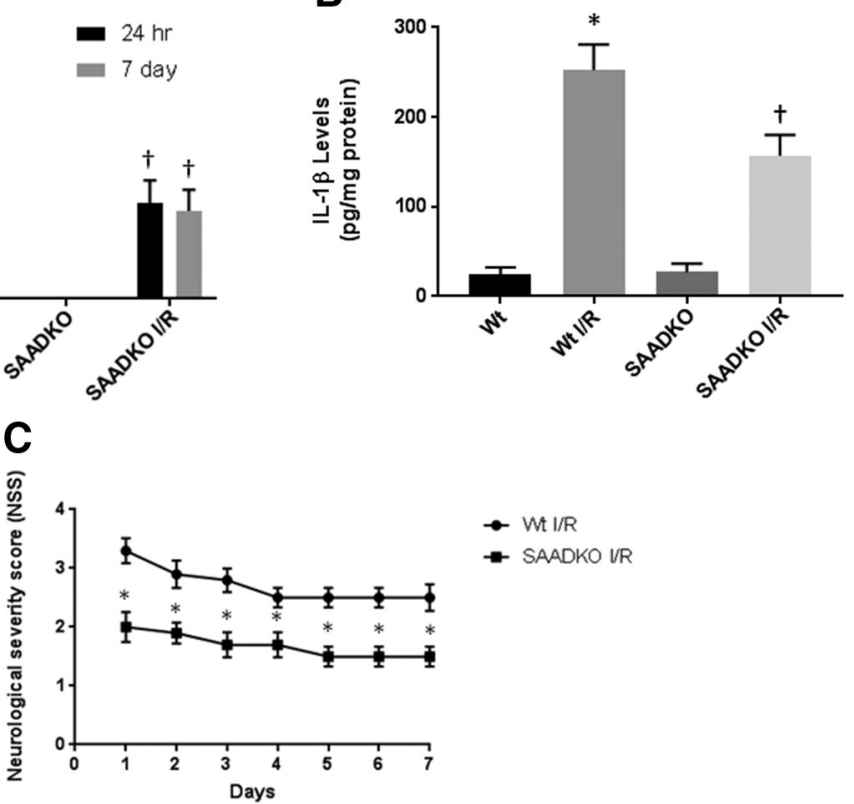

Figure 4. SAA contributes to the infarct volume in cerebral ischemia and enhanced toxicity. $A, C 57 B L / 6$ and SAADKO mice were subjected to $1 \mathrm{~h}$ ischemia and $24 \mathrm{~h}$ or $7 \mathrm{~d}$ of reperfusion $(\mathrm{I} / \mathrm{R})$ and the infarct volume determined. $\boldsymbol{B}$, Brains from mice similarly treated in $\boldsymbol{A}$ were examined for IL-18 levels. $\boldsymbol{C}$, Mice were subjected to Neurological Severity Score (NSS) analysis at each day following the start of reperfusion. Data are mean \pm SE. The measurements are from 8 to 10 mice per treatment. ${ }^{*} p<0.001$
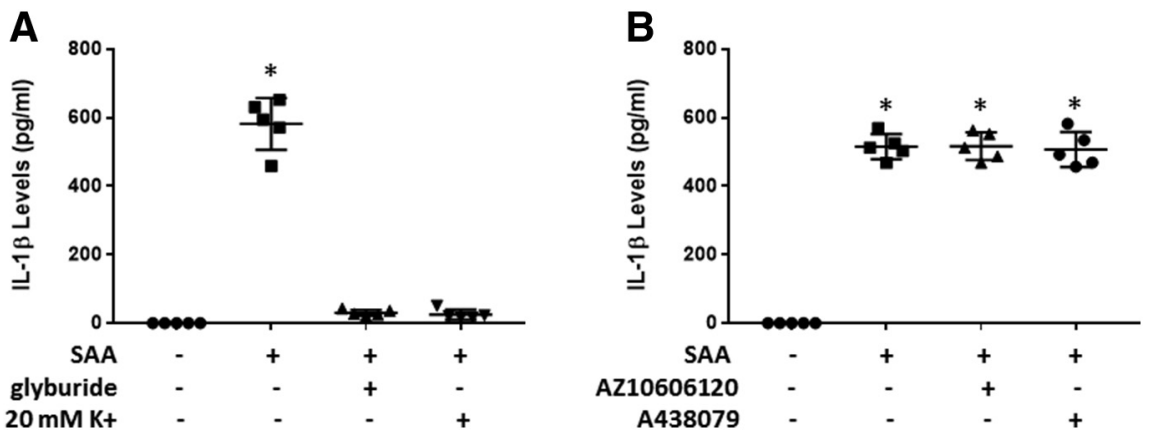

Figure 5. SAA-mediated activation of the inflammasome requires $\mathrm{K}^{+}$efflux and not P2X7R activation. $\boldsymbol{A}, \mathrm{IL}-1 \beta$ levels were measured in the media of BV-2 cells untreated or in the presence of mSAA at $10 \mu \mathrm{g} / \mathrm{ml}$ and $200 \mu \mathrm{m}$ glyburide (potassium channel blocker) or $20 \mathrm{~mm} \mathrm{~K}^{+}$by ELISA. B, IL-1 $\beta$ levels in media from BV-2 cells treated with mSAA $(10 \mu \mathrm{g} / \mathrm{ml}) \pm 10 \mu \mathrm{m} \mathrm{AZ10606120} \mathrm{or}$ cells samples. When $\mathrm{N}$-acetylcysteine (NAC, free-radical scavenger) was added to the cultures, significantly attenuated the increase in ROS associated with SAA treatment. As shown previously, the induction of IL- $1 \beta$ expression by SAA was also prevented by the addition of NAC to the cultures in BV-2 cells (Fig. $6 B$ ). In Figure $6 C$, treatment with NAC only partially blocked the increase in IL- $1 \beta$ mRNA in the BV2 cells. We also tested the effect of a mitochondrial-specific ROS scavenger, mito-TEMPO on SAAmediated changes in IL- $1 \beta$ expression (Fig. 6D). The mitoTEMPO prevented the increase in IL- $\beta$ as did NAC. Finally, we determined the impact of both NAC and mito-TEMPO on primary microglial cells and the production of IL- $1 \beta$ in the presence of SAA (Fig. $6 E, F$ ). As seen with the BV-2 cells, SAA treatment resulted in increased levels of IL-1 $\beta$, and this increase was 
A

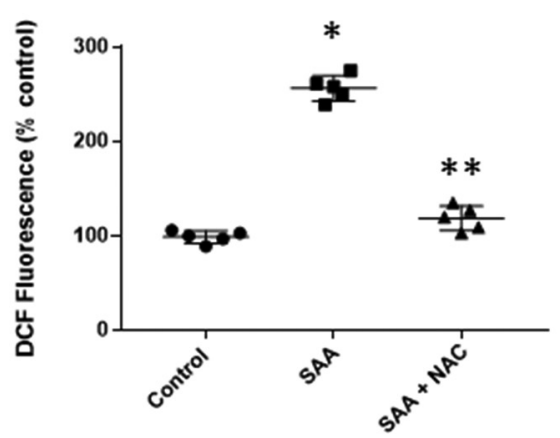

D

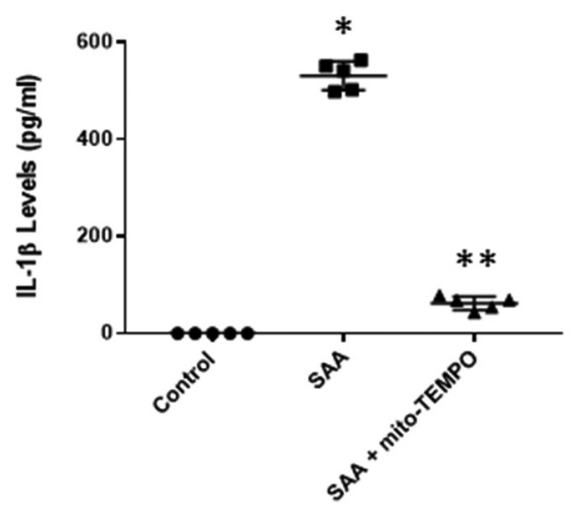

B

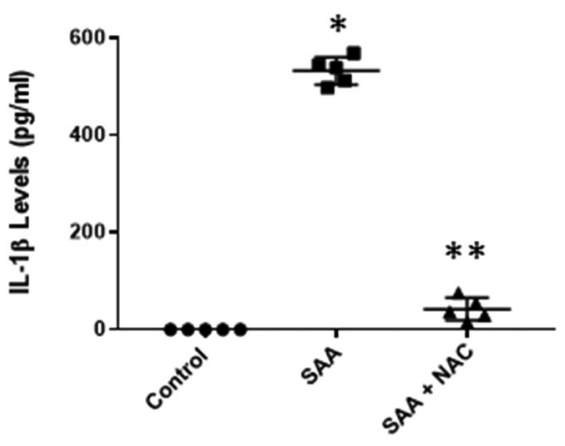

E

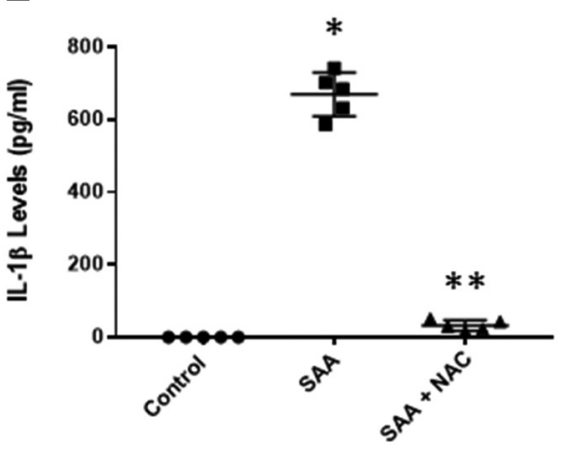

C

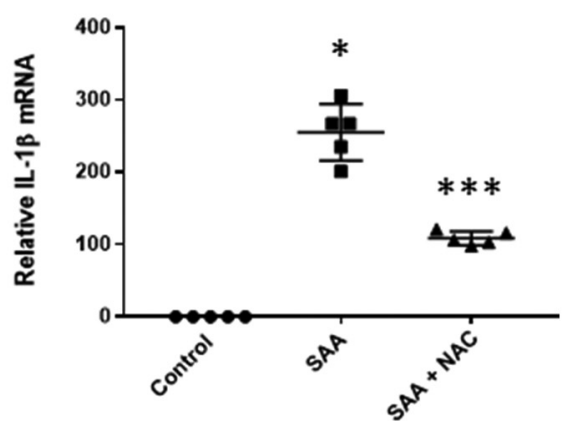

$\mathbf{F}$

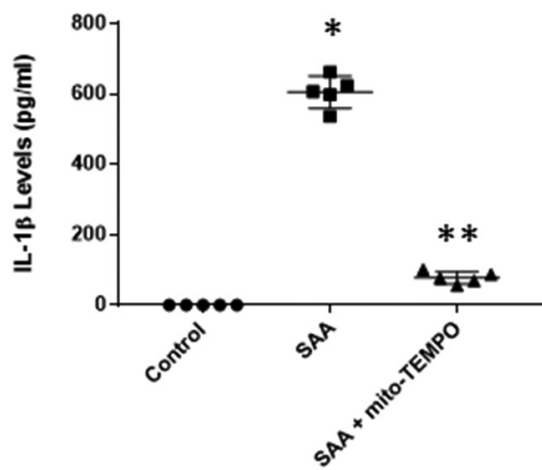

Figure 6. SAA instigates ROS production in microglial cells, and blocking ROS attenuates IL-1 $\beta$ production. $A$, BV- 2 cells were treated with $10 \mu \mathrm{g} / \mathrm{ml}$ of mSAA for $24 \mathrm{~h}$ in the presence or absence of $20 \mu \mathrm{m}$ NAC (free radical scavenger) and were quantified for DCF fluorescence. $B, I L-1 \beta$ levels were determined by ELISA in the media of BV- 2 cells and treated with $10 \mu \mathrm{g} / \mathrm{ml}$ of $\mathrm{mSAA}$ in the presence or absence of $20 \mu \mathrm{m}$ NAC. C, BV-2 microglial cells were incubated with $25 \mu \mathrm{g} / \mathrm{ml}$ of mSAA for $8 \mathrm{~h}$ and assayed for IL- $1 \beta \mathrm{mRNA}$ levels by qRT-PCR. D, IL-1 $\beta$ levels were determined by ELISA in the media of BV-2 cells, incubated with $10 \mu \mathrm{g} / \mathrm{ml} \mathrm{mSAA}$ in the presence or absence of $500 \mu \mathrm{m}$ mito-TEMPO (mitochondria-targeted antioxidant) for $24 \mathrm{~h}$. $E$, Primary mouse microglial cells were incubated with $10 \mu \mathrm{g} / \mathrm{ml}$ of mSAA for $24 \mathrm{~h}$ in the presence or absence of $20 \mu \mathrm{m}$ NAC and assayed for IL- $1 \beta$ mRNA levels by qRT-PCR. $\boldsymbol{F}$, Primary mouse microglial cells were incubated with $10 \mu \mathrm{g} / \mathrm{ml}$ of mSAA in the presence or absence of $500 \mu \mathrm{m}$ mito-TEMPO and the amount of IL- $1 \beta$ in the media determined by ELISA. Data are mean \pm SE. The measurements are from 8 to 10 repeats per treatment. ${ }^{*} p<0.001$ compared with control. ${ }^{* *} p<0.01$ compared to SAA alone. ${ }^{* * *} p<0.001$ compared to control and SAA alone. Data are considered significantly different at $p<0.05$.

blocked by treatment with ROS inhibitors. The studies suggest that SAA action, in part, is mediated through the generation of ROS, and specifically, ROS generated by the mitochondria.

\section{IL- $1 \beta$ production is mediated by SAA induction of cathepsin B}

Previous studies have implicated cathepsin B as a $\beta$-secretase and as an activator of the NLRP3 inflammasome complex (Latz et al., 2013). Cathepsin B is released into the cytoplasm following injury, trauma, or exposure to danger-associated molecular patterns that cause disruption of the lysosomal membrane, and then cathepsin B sparks inflammasome activation (Shridas et al., 2018). To determine the impact of SAA on cathepsin B activation of IL- $1 \beta$ production, BV-2 cells were treated with $10 \mu \mathrm{g} / \mathrm{ml}$ of mSAA as well as several cathepsin B inhibitors (Fig. 7A). As seen in the figure, treatment of BV-2 cells with mSAA in the presence of CA-074Me (catB specific inhibitor), E64d (aspartyl protease inhibitors), or Z-FY-CHO (catL specific inhibitor) at $20 \mu \mathrm{M}$; IL- $1 \beta$ levels were significantly attenuated with the catB $(90 \%$ and 91\% inhibition, respectively) inhibitors, but not the catL inhibitor $(0 \%$ inhibition). To validate these studies, primary microglial cells were isolated from $\mathrm{WT}$, catB $\mathrm{KO}$, and cat $\mathrm{KO}$ and treated with SAA $(10 \mu \mathrm{g} / \mathrm{ml})$, and only the cells from the catB KO mice showed reduced IL-1 $\beta$ levels (Fig. $7 B$ ). Examination of the catB protein levels in the control and SAA-treated BV-2 cells showed that SAA not only released catB from the lysosomes but increased the total protein levels (Fig. 7C,D).

\section{IL- $1 \beta$ production mediated by SAA induction in microglia from receptor-deficient mice}

A number of receptors have been implicated in the signaling mechanisms associated with SAA-mediated cellular actions. Our previous studies have suggested that AA amyloid and SAA may function through the receptor for advanced glycation endproducts (RAGE) (Yan et al., 2000). To determine the receptors that may mediate the effects of SAA on microglial cells, we isolated cells from RAGE KO, TLR2/4 KO, and RAGE/TLR2/4 KO mice (Fig. 8). As seen in the figure, SAA activated IL- $1 \beta$ expression in WT microglia but was significantly blunted in RAGE KO, TLR2/4, and RAGE/TLR2/4 KO mice. These data suggest that all three receptors may function in a tripartite fashion to activate the inflammasome complex (Baranova et al., 2017).

\section{Induction of proinflammatory cytokines and M1 phenotype in microglial cells by SAA}

As previously indicated, SAA induces a proinflammatory condition by stimulation of proinflammatory cytokines. To determine the impact of SAA on BV-2 cells, SAA induced the expression of both TNF- $\alpha$ and IL- 6 mRNA and protein in a dose-dependent fashion, similar to the increase by LPS (Fig. $9 A, B, D, E$ ). Like 
macrophages, microglial cells have altered phenotypes depending on the inflammatory nature of the cells (Shridas et al., 2018). When the BV-2 cells are treated with LPS or SAA, the BV-2 cells express the M1 inducible nitric oxide synthase (iNOS) when treated with SAA in a dosedependent fashion (Fig. 9C). Additionally, when primary microglial cells are incubated with SAA and different concentrations, they show an increase in TNF- $\alpha$, IL-6, and iNOS (Fig. 9F-H). These data suggest that SAA induces a M1 proinflammatory process in the microglial cells that will have an impact on brain function following injury.

\section{Inhibition of anti-inflammatory cytokines and M2 phenotype in microglial cells by SAA}

As indicated above, microglial cells demonstrate different phenotypes representative of proinflammatory or antiinflammatory activities. Since SAA induces an M1 phenotype (Fig. 8), we examined the impact of SAA on antiinflammatory M2 phenotype (Fig. 10). M2 phenotype is determined by the expression of specific proteins, such as arginase-1 (Arg-1), CD206, and Fizz1. As seen in the figure, incubation of the BV-2 cells with SAA at different concentrations (along with LPS) did not induce an M2 phenotype that was seen in the presence of dexmedetomidine. Both in BV-2 cells (Fig. 10A-C) and primary microglial cells (Fig. $10 D, E)$, mSAA did not induce an M2 phenotype. In Figure $10 G$, $H$, SAA actually reduced the levels of Arg- 1 in the cells. When dexmedetomidine and SAA were incubated together, SAA prevented an M2 phenotype (Fig. 10I). These data suggest that SAA is capable of inducing an M1 proinflammatory and preventing an M2 anti-inflammatory phenotype in the microglial cells.

\section{Discussion}

The experiments performed in this study demonstrated that SAA plays an important role in the activation of microglial cells and in the production of IL- $1 \beta$ mediated by the inflammasome. Previous studies have demonstrated that plasma SAA levels are elevated in neurological diseases, such as stroke and TBI, and that IL- $1 \beta$ and the NLRP3 inflammasome may contribute to the development and progression of these disorders (Azurmendi et al., 2017). These findings are significant in that they suggest that SAA is a vital factor involved in activation of IL- $1 \beta$ and the secretion of SAA in the disease process is indicative of disease modification. Therefore, a better understanding of the mechanisms associated with increased SAA levels and the relationship to inflammasome activation may provide unique approaches to treat or reduce the impact of the disease.

SAAs are acute-phase proteins that are increased 1000-fold in response to inflammatory signals and mainly produced in hepatocytes (Liao et al., 1994). During the acute phase, SAA is normally found on HDL particles and converts the antiinflammatory nature of the HDL to a pro-inflammatory entity that contributes to a number of different diseases, including atherosclerosis (Feingold and Grunfeld, 2016). Over the years, stud-
B
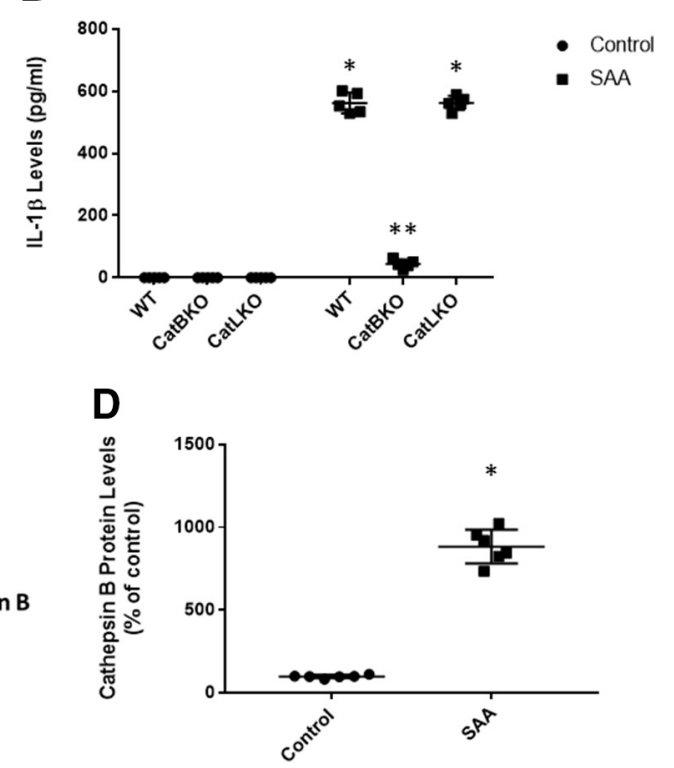

Figure 7. IL- $1 \beta$ production is mediated by SAA induction of cathepsin B. A, IL- $1 \beta$ levels in BV- 2 cells were determined by ELISA 列 $10 \mu \mathrm{g} / \mathrm{ml} \mathrm{mSAA} \mathrm{for} 24 \mathrm{~h}$ in the presence or absence of CA-074Me or E64d (cathepsin B inhibitors) or Z-FY-CHO tative analysis of Western blots in $C$. Data are mean \pm SE. The measurements are from 8 to 10 repeats per treatment. ${ }^{*} p<0.001$ compared with control. ${ }^{* *} p<0.001$ compared with treated cells. Data are considered significantly different at $p<0.05$.

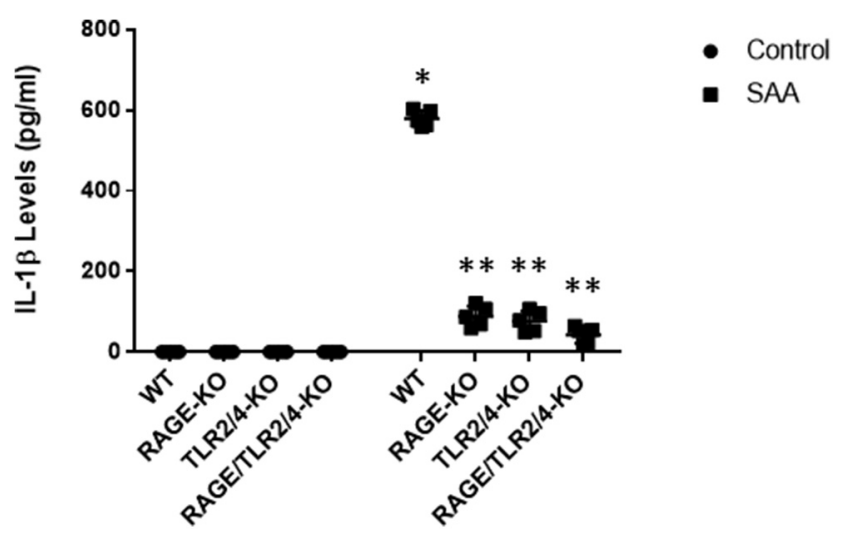

Figure 8. IL-1 $\beta$ production mediated by SAA induction in microglia from receptor-deficient mice. IL-1 $\beta$ levels were determined by ELISA in primary microglial cells isolated from receptordeficient mice (RAGE, TLR2/4, and RAGE/TLR2/4 KO mice) after treatment with vehicle or 10 $\mu \mathrm{g} / \mathrm{ml} \mathrm{mSAA}$ for $24 \mathrm{~h}$. KO mice were verified by PCR analysis. Data are mean $\pm \mathrm{SE}$. The measurements are from 8 to 10 repeats per treatment. ${ }^{*} p<0.001$ compared with control. ${ }^{* *} p<$ 0.001 compared with WT cells. Data are considered significantly different at $p<0.05$.

ies have indicated that SAAs can exist in the absence of HDL and contribute to inflammation, amyloidosis, rheumatoid arthritis, etc. (Gavrila et al., 2016; Getz et al., 2016; Dieter et al., 2019; Vahdat Shariat Panahi et al., 2019). Also, SAAs have been shown to stimulate a number of different types of cells, macrophages, dendritic cells, neutrophils, and even microglia to induce IL-1 $\beta$ and other inflammatory signals, some mediated by the inflammasome (Ather et al., 2011). We have shown that purified mSAA and hSAA were able to induce microglia response in both mouse and human microglial cell lines. In addition, the SAA proteins come in several different flavors (Sack, 2018). In the mouse, SAA1.1, SAA2.1, and SAA3 demonstrate acute-phase activity 

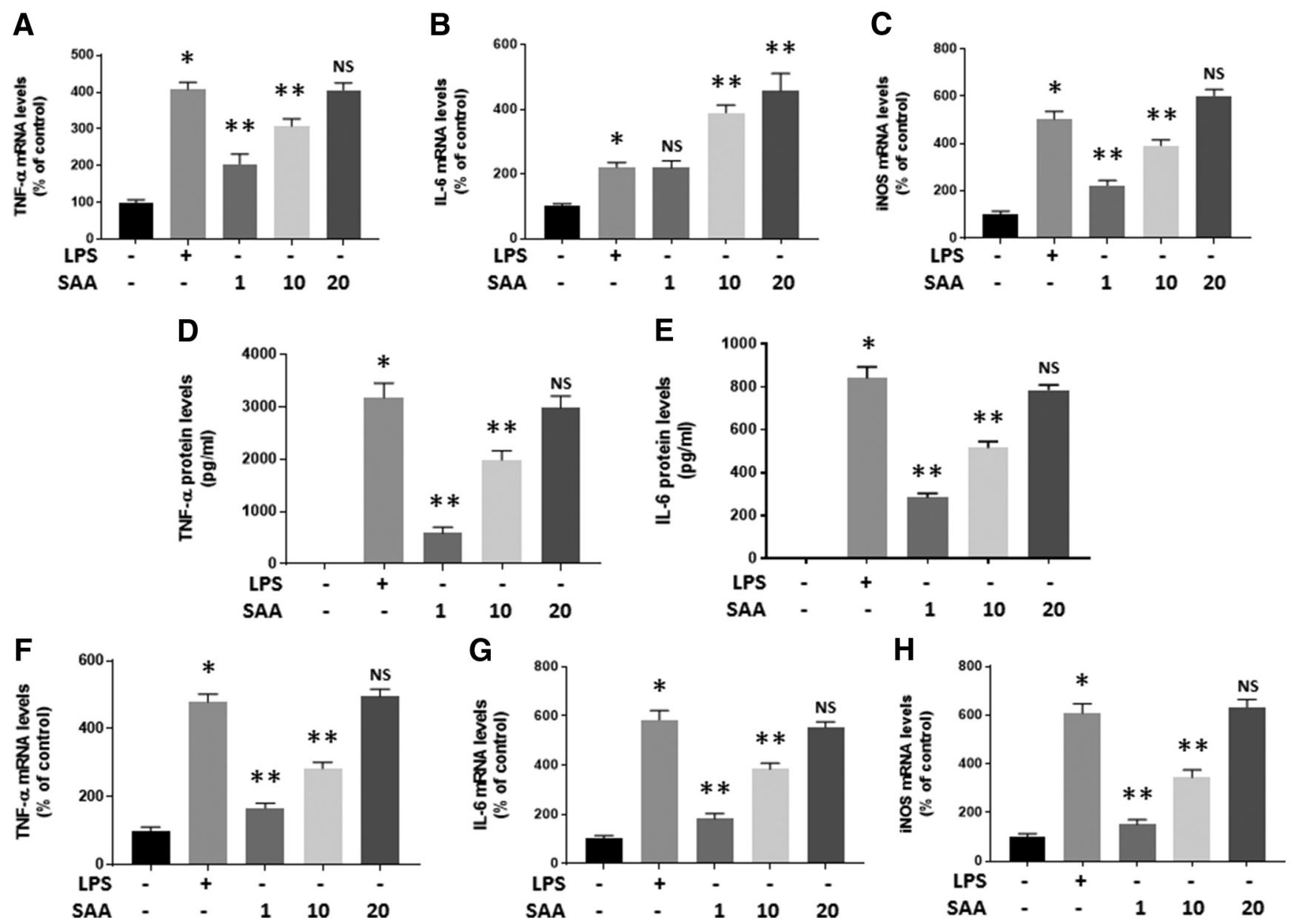

Figure 9. Induction of proinflammatory cytokines and M1 phenotype in microglial cells by SAA. $\boldsymbol{A}-\boldsymbol{C}$, Induction of TNF- $\alpha(\boldsymbol{A})$, IL-6 (B), and iNOS (C) mRNA in BV-2 cells by mSAA at the indicated concentrations for $12 \mathrm{~h}$ and determined by qRT-PCR. $\boldsymbol{D}, \boldsymbol{E}$, TNF- $\alpha(\boldsymbol{D})$ and IL- $6(\boldsymbol{E})$ protein levels in the media of BV-2 cells by mSAA at the indicated concentrations for $24 \mathrm{~h}$ by ELISA. $\boldsymbol{F}-\boldsymbol{H}$, Induction of TNF- $\alpha(\boldsymbol{A}), \mathrm{IL}-6(\boldsymbol{B})$, and iNOS mRNA $(\boldsymbol{C})$ in primary microglial cells by mSAA at the indicated concentrations for $12 \mathrm{~h}$ and determined by $q \mathrm{RT}-\mathrm{PCR}$. Data are mean \pm SE. The measurements are from 8 to 10 repeats per treatment. ${ }^{*} p<0.001$ compared with control. ${ }^{* *} p<0.001$ compared with LPS-treated cells. NS, Not significant compared with LPS-treated cells. Data are considered significantly different at $p<0.05$.

(SAA3 not as much); whereas in humans, SAA1 and SAA2 are the major acute-phase SAA proteins (Kindy et al., 2000). SAA3 in humans is a pseudogene, and the SAA4 protein is constitutively expressed in both mouse and humans. Our studies here show that both SAA1.1 and SAA2.1 isoforms are equivalent in their ability to induce IL- $1 \beta$ induction.

Activation of the NLRP3 inflammasome can occur via various mechanisms (Ather et al., 2011). The NLRP3 must be primed before activation, and this process involves two discrete steps. The first, an NF- $\kappa \mathrm{B}$ - and MAPK-activating stimulus, such as danger-associated molecular patterns binding to pattern recognition receptors (TLRs, RAGE, and IL-1R1), induces elevated expression of NLRP3 inflammasome proteins, and pro-IL-1 and pro-IL-18 (Ather et al., 2011). After priming, the second signal required to activate NLRP3 and lead to the formation of the NLRP3 inflammasome complex. The stimuli include potassium efflux through ion channels, cathepsin B release following lysosomal membranes destabilization, intracellular $\mathrm{Ca}^{2+}$ accumulation, cell swelling, and the sensation of mitochondrial factors released into the cytosol (ROS). These stimuli trigger the NLRP3 inflammasome complex by facilitating the oligomerization of NLRP3, ASC, and procaspase-1 (Sack, 2018). This process results in the activation pro-caspase- 1 into cleaved caspase- 1 , which catalyzes the transformation from proIL-1b and proIL-18 into
IL-1 $\beta$ and IL-18. During ischemia and reperfusion injury, influx of $\mathrm{Ca}^{2+}$ ions, generation of lactic acid, and destabilization of lysosomal membrane can all lead to activation of the NLRP3 inflammasome (Bu et al., 2019). In addition, release of ATP binds to the $\mathrm{P} 2 \mathrm{X} 4$ and $\mathrm{P} 2 \mathrm{X} 7$ receptors on the neurons, astrocytes, or microglia, which leads to the efflux of $\mathrm{K}^{+}$ions, and decrease in intracellular $\mathrm{K}^{+}$concentration leads to NLRP3 activation (Richter et al., 2017). Finally, mitochondria changes during ischemic injury, increases ROS formation in the cytoplasm, which leads to TXNIP and NLRP3 stimulation. We have shown that SAA activates the inflammasome by mediating ROS in the microglial cells through the inhibition by NAC and mito-TEMPO. The release of cathepsin B by SAA through lysosomal degradation was demonstrated by inhibition of cathepsin B, leading to attenuation of NLRP3 activation. Finally, blocking $\mathrm{K}^{+}$efflux also inhibited the increase in IL- $1 \beta$ release. Therefore, the presence of SAA leads to further activation of the NLRP3 inflammasome in the brain.

The activation of caspase- 1 and the production/release of IL- $1 \beta$ and IL-18 initiate programmed cell death pathways, such as pyroptosis and necroptosis (Martinet et al., 2019; Van Opdenbosch and Lamkanfi, 2019). Caspase-1 results in the cleavage of a cytoplasmic protein referred to as gasdermin D (GSDMD), which promotes the formation of GSDMD membrane pores, which leads to cell lysis (Pandeya et al., 2019). This family of 

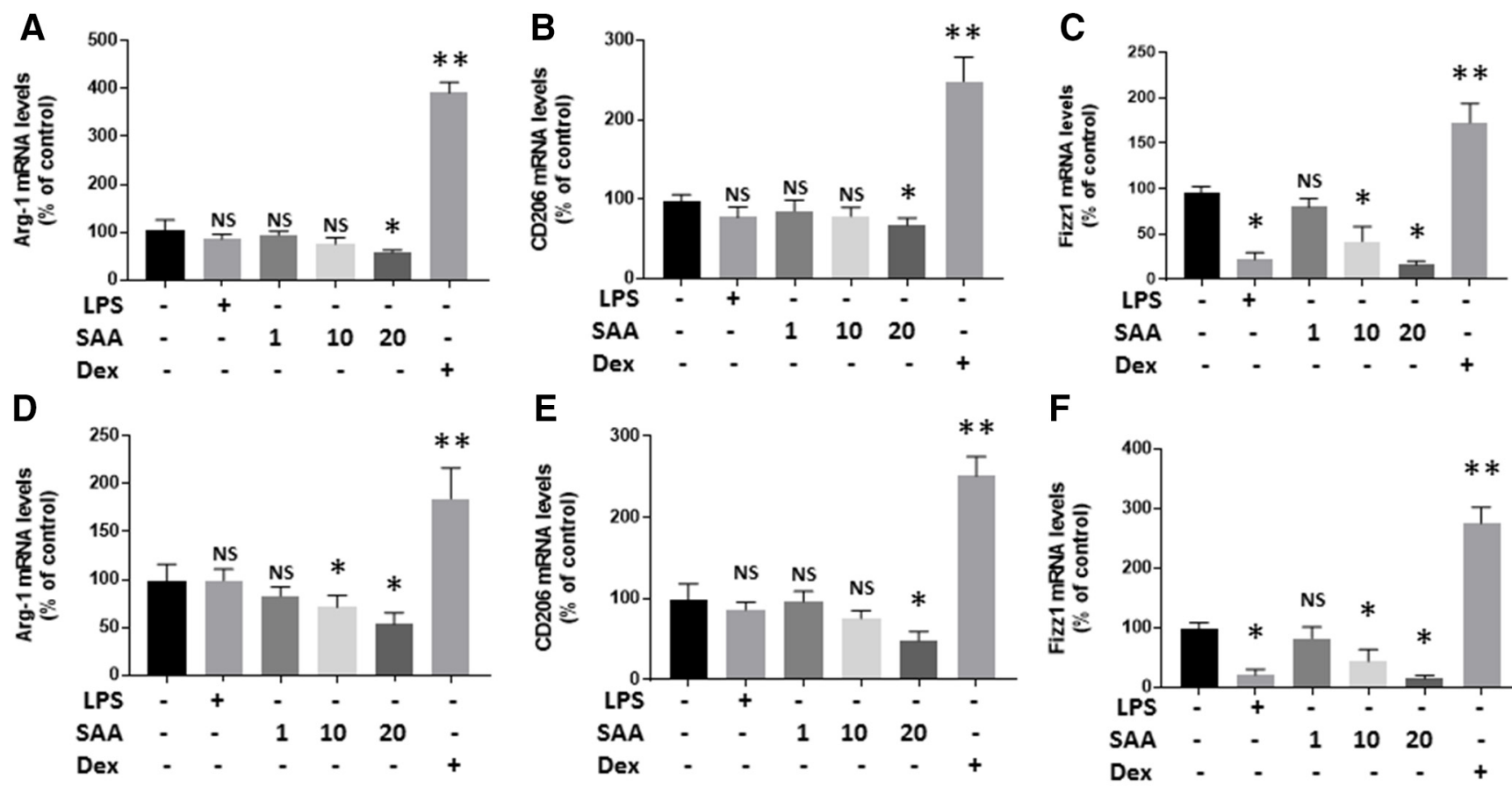

$\mathbf{F}$

G

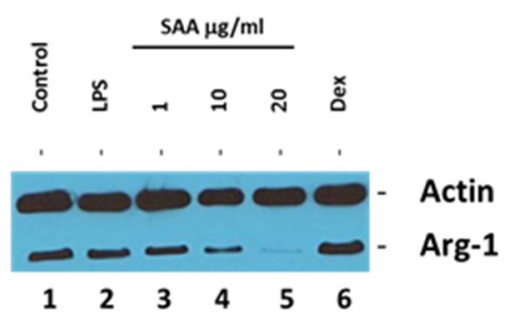

H

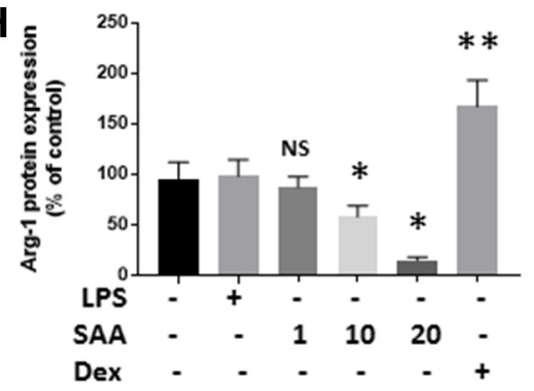

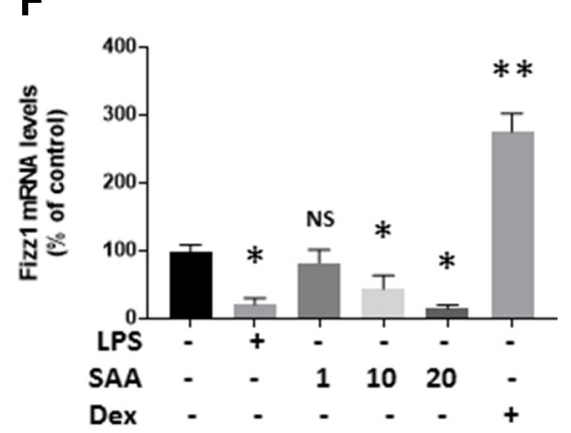

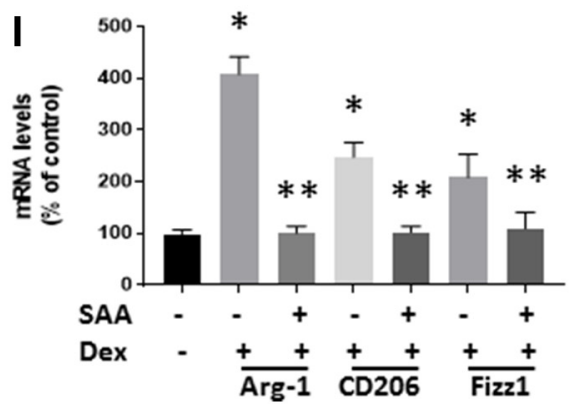

Figure 10. Inhibition of anti-inflammatory cytokines and M2 phenotype in microglial cells by SAA. $A-C$, Evaluation of Arg-1 (A), CD206 (B), and Fizz1 (C) mRNA in BV-2 cells by mSAA or dexmedetomidine (Dex) at the indicated concentrations for $12 \mathrm{~h}$ and determined by qRT-PCR. $\boldsymbol{D}-\boldsymbol{F}$, Evaluation of Arg-1 (D), CD206 (E), and Fizz1 (F) mRNA in primary microglial cells by mSAA or Dex at the indicated concentrations for $12 \mathrm{~h}$ and determined by qRT-PCR. G, Representative Western blot of proteins isolated from BV-2 cells treated with $1-20 \mu \mathrm{g} / \mathrm{ml}$ of $\mathrm{mSAA}$ for $24 \mathrm{~h}$ probed for $\beta$-actin and Arg-1. H, Quantitative analysis of Western blots in G.I, Evaluation of Arg-1, CD206, and Fizz1 mRNA in BV-2 microglial cells by mSAA and/or Dex at $12 \mathrm{~h}$ and determined by qRT-PCR. Data are mean \pm SE. The measurements are from 8 to 10 repeats per treatment. ${ }^{*} p<0.001$ compared with control. ${ }^{* *} p<0.001$ compared with WT cells. Data are considered significantly different at $p<0.05$. NS, not significant.

proteins encode large 12-20 nm oligomeric membrane pores that form in both the cell membrane as well as intracellular organelles, but GSDMD is the only constituent that responds to inflammatory caspases (Tonnus et al., 2019). So the stimulation of microglia (and possibly macrophages) by SAA contributes to activation and secretion of IL-1 $\beta$ and IL-18, pyroptosis, and release of additional DMAPs, which further exacerbate the disease process (Voet et al., 2019; Wang et al., 2019). Since the IL-1 $\beta$ and IL-18 lack secretion signals, the release of the entities from glial cells activated in disease is most likely related to pyroptosis (Zhaolin et al., 2019), although transient secretion of NLRP3 leaderless cytokines can be seen under certain conditions (Herman and Pasinetti, 2018). Therefore, the role of SAA in activation of the glial cells following cerebral ischemia and stroke results in activation of pyroptosis and the eventual release of IL- $1 \beta / \mathrm{IL}-18$, which aggravates the outcomes (Platnich and Muruve, 2019).

One concern, pointed out by Shridas et al. (2018), is that SAA is predominantly found associated with HDL particles. During inflammation or an acute-phase response, SAA becomes the major apolipoprotein on the HDL particles (Kindy et al., 2000). Throughout this process, SAA is exchanged for apoA-1 on the HDL, converting the normal anti-inflammatory nature of the
HDL to a pro-inflammatory entity. This in turn appears to play a role in the pathogenesis of HDL possibly contributing to atherosclerosis, cardiovascular disease, and possibly amyloidoses. However, of the many studies on SAA, these have been the result of experiments with purified SAA or rather non-HDL bound SAA (Shridas et al., 2018). Shridas et al. (2018) showed that, when SAA was HDL-associated, the various biological effects of increased NLRP3 activation were attenuated. Two possibilities exist to explain the data presented here and in other reports on the impact of SAA. First, SAA, which is HDL-associated, might be dissociated from the HDL when it reaches a target organ, such as the heart, brain, or vasculature, by interaction with any of the various "SAA receptors" or through some process that alters the structure of the HDL to allow the SAA to be released (Yan et al., 2000). A second possibility is that SAA is locally produced and gives rise to many of the effects seen in inflammation (Sano et al., 2015). It is possible that both may occur and this process gives rise to inflammasome activation in the tissue and exacerbates the disease pathogenesis.

In the present study, SAA can induce that activation of the inflammasome in microglial cells and give rise to IL- $1 \beta$ release, which can further inflammation in the brain following neurolog- 
ical diseases. We and others have shown that plasma SAA is induced following stroke or TBI and that $S A A \mathrm{KO}$ mice have reduced inflammation and reduction infarct or lesion volumes (Chen et al., 2018; Wicker et al., 2019). It is likely that the ischemia and reperfusion injury or TBI results in the release of inflammatory mediators from the brain (i.e., IL- $1 \beta$, IL-6, TNF- $\alpha$, and others that travel to the other organs, including the liver), which results in the activation of SAA (Kindy et al., 2000). This results in the generation of SAA-HDL which can flow back to the brain; and with the breakdown of the blood-brain barrier, the SAA may interact with neurons and glia to cause further inflammasome activation and cell death. How these processes work is not known, and additional investigation is needed to determine the mechanisms associated with SAA contribution to stroke and TBI.

\section{References}

Arancio O, Zhang HP, Chen X, Lin C, Trinchese F, Puzzo D, Liu S, Hegde A, Yan SF, Stern A, Luddy JS, Lue LF, Walker DG, Roher A, Buttini M, Mucke L, Li W, Schmidt AM, Kindy M, Hyslop PA, et al. (2004) RAGE potentiates Abeta-induced perturbation of neuronal function in transgenic mice. EMBO J 23:4096-4105.

Ather JL, Ckless K, Martin R, Foley KL, Suratt BT, Boyson JE, Fitzgerald KA, Flavell RA, Eisenbarth SC, Poynter ME (2011) Serum amyloid A activates the NLRP3 inflammasome and promotes Th17 allergic asthma in mice. J Immunol 187:64-73.

Azurmendi L, Lapierre-Fetaud V, Schneider J, Montaner J, Katan M, Sanchez JC (2017) Proteomic discovery and verification of serum amyloid A as a predictor marker of patients at risk of post-stroke infection: a pilot study. Clin Proteomics 14:27.

Baird TA, Parsons MW, Barber PA, Butcher KS, Desmond PM, Tress BM, Colman PG, Jerums G, Chambers BR, Davis SM (2002) The influence of diabetes mellitus and hyperglycemia on stroke incidence and outcome. J Clin Neurosci 9:618-626.

Baranova IN, Souza AC, Bocharov AV, Vishnyakova TG, Hu X, Vaisman BL, Amar MJ, Chen Z, Remaley AT, Patterson AP, Yuen PS, Star RA, Eggerman TL (2017) Human SR-BII mediates SAA uptake and contributes to SAA pro-inflammatory signaling in vitro and in vivo. PLoS One 12: e0175824.

Bauer C, Duewell P, Mayer C, Lehr HA, Fitzgerald KA, Dauer M, Tschopp J, Endres S, Latz E, Schnurr M (2010) Colitis induced in mice with dextran sulfate sodium (DSS) is mediated by the NLRP3 inflammasome. Gut 59:1192-1199.

Becker KJ (2002) Anti-leukocyte antibodies: LeukArrest (Hu23F2G) and enlimomab (R6.5) in acute stroke. Curr Med Res Opin 18:S18-S22.

Brea D, Sobrino T, Blanco M, Fraga M, Agulla J, Rodríguez-Yáñez M, Rodríguez-González R, Pérez de la Ossa N, Leira R, Forteza J, Dávalos A, Castillo J (2009) Usefulness of haptoglobin and serum amyloid A proteins as biomarkers for atherothrombotic ischemic stroke diagnosis confirmation. Atherosclerosis 205:561-567.

Bu J, Shi S, Wang HQ, Niu XS, Zhao ZF, Wu WD, Zhang XL, Ma Z, Zhang YJ, Zhang H, Zhu Y (2019) Acacetin protects against cerebral ischemiareperfusion injury via the NLRP3 signaling pathway. Neural Regen Res 14:605-612.

Cai X, Chen J, Xu H, Liu S, Jiang QX, Halfmann R, Chen ZJ (2014) Prionlike polymerization underlies signal transduction in antiviral immune defense and inflammasome activation. Cell 156:1207-1222.

Chen W, Lin A, Yu Y, Zhang L, Yang G, Hu H, Luo Y (2018) Serum soluble ST2 as a novel inflammatory marker in acute ischemic stroke. Clin Lab 64:1349-1356.

Connolly M, Mullan RH, McCormick J, Matthews C, Sullivan O, Kennedy A, FitzGerald O, Poole AR, Bresnihan B, Veale DJ, Fearon U (2012) Acutephase serum amyloid A regulates tumor necrosis factor $\alpha$ and matrix turnover and predicts disease progression in patients with inflammatory arthritis before and after biologic therapy. Arthritis Rheum 64:10351045.

de Beer MC, Webb NR, Wroblewski JM, Noffsinger VP, Rateri DL, Ji A, van der Westhuyzen DR, de Beer FC (2010) Impact of serum amyloid A on high density lipoprotein composition and levels. J Lipid Res 51:31173125 .
Dieter BP, Meek RL, Anderberg RJ, Cooney SK, Bergin JL, Zhang H, Nair V, Kretzler M, Brosius FC, Tuttle KR (2019) Serum amyloid A and Janus kinase 2 in a mouse model of diabetic kidney disease. PLoS One 14:e0211555.

Donnan GA, Fisher M, Macleod M, Davis SM (2008) Stroke. Lancet 371:1612-1623.

Duncan JA, Bergstralh DT, Wang Y, Willingham SB, Ye Z, Zimmermann AG, Ting JP (2007) Cryopyrin/NALP3 binds to ATP/dATP, is an ATPase, and requires ATP binding to mediate inflammatory signaling. Proc Natl Acad Sci U S A 104:8041-8046.

Elkind MS, Cheng J, Rundek T, Boden-Albala B, Sacco RL (2004) Leukocyte count predicts outcome after ischemic stroke: the Northern Manhattan Stroke Study. J Stroke Cerebrovasc Dis 13:220-227.

Emsley HC, Hopkins SJ (2008) Acute ischaemic stroke and infection: recent and emerging concepts. Lancet Neurol 7:341-353.

Enlimomab Acute Stroke Trial Investigators (2001) Use of anti-ICAM-1 therapy in ischemic strokes: results of the Enlimomab Acute Stroke Trial. Neurology 57:1428-1434.

Feingold KR, Grunfeld C (2016) Effect of inflammation on HDL structure and function. Curr Opin Lipidol 27:521-530.

Gao L, Dong Q, Song Z, Shen F, Shi J, Li Y (2017) NLRP3 inflammasome: a promising target in ischemic stroke. Inflamm Res 66:17-24.

Garg NJ (2011) Inflammasomes in cardiovascular diseases. Am J Cardiovasc Dis $1: 244-254$.

Gavrila BI, Ciofu C, Stoica V (2016) Biomarkers in rheumatoid arthritis: what is new? J Med Life 9:144-148.

Getz GS, Krishack PA, Reardon CA (2016) Serum amyloid A and atherosclerosis. Curr Opin Lipidol 27:531-535.

Gross O, Thomas CJ, Guarda G, Tschopp J (2011) The inflammasome: an integrated view. Immunol Rev 243:136-151.

Herman FJ, Pasinetti GM (2018) Principles of inflammasome priming and inhibition: implications for psychiatric disorders. Brain Behav Immun 73:66-84.

Herman FJ, Simkovic S, Pasinetti GM (2019) Neuroimmune nexus of depression and dementia: Shared mechanisms and therapeutic targets. Br J Pharmacol 176:3558-3584.

Hook GR, Yu J, Sipes N, Pierschbacher MD, Hook V, Kindy MS (2014) The cysteine protease cathepsin B is a key drug target and cysteine protease inhibitors are potential therapeutics for traumatic brain injury. J Neurotrauma 31:515-529.

Keller JN, Hanni KB, Gabbita SP, Friebe V, Mattson MP, Kindy MS (1999) Oxidized lipoproteins increase reactive oxygen species formation in microglia and astrocyte cell lines. Brain Res 830:10-15.

Kim MH, de Beer MC, Wroblewski JM, Webb NR, de Beer FC (2013) SAA does not induce cytokine production in physiological conditions. Cytokine 61:506-512.

Kindy MS, de Beer MC, Yu J, de Beer FC (2000) Expression of mouse acutephase (SAA1.1) and constitutive (SAA4) serum amyloid A isotypes: influence on lipoprotein profiles. Arterioscler Thromb Vasc Biol 20:15431550 .

Lamkanfi M, Dixit VM (2009) Inflammasomes: guardians of cytosolic sanctity. Immunol Rev 227:95-105.

Lamkanfi M, Mueller JL, Vitari AC, Misaghi S, Fedorova A, Deshayes K, Lee WP, Hoffman HM, Dixit VM (2009) Glyburide inhibits the Cryopyrin/ Nalp3 inflammasome. J Cell Biol 187:61-70.

Latz E, Xiao TS, Stutz A (2013) Activation and regulation of the inflammasomes. Nat Rev Immunol 13:397-411.

Liao F, Lusis AJ, Berliner JA, Fogelman AM, Kindy M, de Beer MC, de Beer FC (1994) Serum amyloid A protein family: differential induction by oxidized lipids in mouse strains. Arterioscler Thromb 14:1475-1479.

Martinet W, Coornaert I, Puylaert P, De Meyer GR (2019) Macrophage death as a pharmacological target in atherosclerosis. Front Pharmacol 4:306.

Martinon F, Tschopp J (2007) Inflammatory caspases and inflammasomes: master switches of inflammation. Cell Death Differ 14:10-22.

Martinon F, Burns K, Tschopp J (2002) The inflammasome: a molecular platform triggering activation of inflammatory caspases and processing of proIL-beta. Mol Cell 10:417-426.

McColl BW, Rothwell NJ, Allan SM (2007) Systemic inflammatory stimulus potentiates the acute phase and $\mathrm{CXC}$ chemokine responses to experimental stroke and exacerbates brain damage via interleukin-1- and neutrophil-dependent mechanisms. J Neurosci 27:4403-4412. 
McColl BW, Allan SM, Rothwell NJ (2009) Systemic infection, inflammation and acute ischemic stroke. Neuroscience 158:1049-1061.

Migita K, Koga T, Komori A, Torigoshi T, Maeda Y, Izumi Y, Sato J, Jiuchi Y, Miyashita T, Yamasaki S, Kawakami A, Nakamura M, Motokawa S, Ishibashi H (2011) Influence of Janus kinase inhibition on interleukin 6-mediated induction of acute-phase serum amyloid $\mathrm{A}$ in rheumatoid synovium. J Rheumatol 38:2309-2317.

Nakamura T (2011) Amyloid A amyloidosis secondary to rheumatoid arthritis: pathophysiology and treatment. Clin Exp Rheumatol 29:850-857.

Pandeya A, Li L, Li Z, Wei Y (2019) Gasdermin D (GSDMD) as a new target for the treatment of infection. Medchemcomm 10:660-667.

Pedra JH, Cassel SL, Sutterwala FS (2009) Sensing pathogens and danger signals by the inflammasome. Curr Opin Immunol 21:10-16.

Platnich JM, Muruve DA (2019) NOD-like receptors and inflammasomes: a review of their canonical and non-canonical signaling pathways. Arch Biochem Biophys 670:4-14.

Prestigiacomo CJ, Kim SC, Connolly ES Jr,Liao H, Yan SF, Pinsky DJ (1999) CD18-mediated neutrophil recruitment contributes to the pathogenesis of reperfused but not nonreperfused stroke. Stroke 30:1110-1117.

Richter F, Eitner A, Leuchtweis J, Bauer R, Lehmenkühler A, Schaible HG (2017) Effects of interleukin- $1 \beta$ on cortical spreading depolarization and cerebral vasculature. J Cereb Blood Flow Metab 37:1791-1802.

Sack GH Jr (2018) Serum amyloid A: a review. Mol Med 24:46.

Sano T, Huang W, Hall JA, Yang Y, Chen A, Gavzy SJ, Lee JY, Ziel JW, Miraldi ER, Domingos AI, Bonneau R, Littman DR (2015) An IL-23R/IL-22 circuit regulates epithelial serum amyloid A to promote local effector Th17 responses. Cell 163:381-393.

Schmidt FI, Lu A, Chen JW, Ruan J, Tang C, Wu H, Ploegh HL (2016) A single domain antibody fragment that recognizes the adaptor ASC defines the role of ASC domains in inflammasome assembly. J Exp Med 213:771-790.

Shridas P, De Beer MC, Webb NR (2018) High-density lipoprotein inhibits serum amyloid A-mediated reactive oxygen species generation and NLRP3 inflammasome activation. J Biol Chem 293:13257-13269.

Targonska-Stepniak B, Dryglewska M, Majdan M (2010) Influence of longterm leflunomide treatment on serum amyloid concentration in rheumatoid arthritis patients. Pharmacol Rep 62:719-725.

Tonnus W, Meyer C, Paliege A, Belavgeni A, von Mässenhausen A, Bornstein SR, Hugo C, Becker JU, Linkermann A (2019) The pathological features of regulated necrosis. J Pathol 247:697-707.

Vahdat Shariat Panahi A, Hultman P, Öllinger K, Westermark GT, Lundmark $\mathrm{K}$ (2019) Lipid membranes accelerate amyloid formation in the mouse model of AA amyloidosis. Amyloid 30:1-11.

Van Opdenbosch N, Lamkanfi M (2019) Caspases in cell death, inflammation, and disease. Immunity 50:1352-1364.
Voet S, Srinivasan S, Lamkanfi M, van Loo G (2019) Inflammasomes in neuroinflammatory and neurodegenerative diseases. EMBO Mol Med 11:e10248.

Wang S, Yuan YH, Chen NH, Wang HB (2019) The mechanisms of NLRP3 inflammasome/pyroptosis activation and their role in Parkinson's disease. Int Immunopharmacol 67:458-464.

Wang X (2005) Investigational anti-inflammatory agents for the treatment of ischemic brain injury. Expert Opin Investig Drugs 14:393-409.

Wang Z, Nakayama T (2010) Inflammation, a link between obesity and cardiovascular disease. Mediators Inflamm 2010:535918.

Webb NR, Cai L, Ziemba KS, Yu J, Kindy MS, van der Westhuyzen DR, de Beer FC (2002) The fate of HDL particles in vivo after SR-BI-mediated selective lipid uptake. J Lipid Res 43:1890-1898.

Wicker E, Benton L, George K, Furlow W, Villapol S (2019) Serum amyloid A protein as a potential biomarker for severity and acute outcome in traumatic brain injury. Biomed Res Int 2019:5967816.

Xie X, Ma YT, Yang YN, Fu ZY, Li XM, Huang D, Ma X, Chen BD, Liu F (2010) Polymorphisms in the SAA1/2 gene are associated with carotid intima media thickness in healthy Han Chinese subjects: the cardiovascular risk survey. PLoS One 5:e13997.

Yan SD, Zhu H, Zhu A, Golabek A, Du H, Roher A, Yu J, Soto C, Schmidt AM, Stern D, Kindy M (2000) Receptor-dependent cell stress and amyloid accumulation in systemic amyloidosis. Nat Med 6:643-651.

Yang RZ, Lee MJ, Hu H, Pollin TI, Ryan AS, Nicklas BJ, Snitker S, Horenstein RB, Hull K, Goldberg NH, Goldberg AP, Shuldiner AR, Fried SK, Gong DW (2006) Acute-phase serum amyloid A: an inflammatory adipokine and potential link between obesity and its metabolic complications. PLoS Med 3:e287.

Ye Z, Ting JP (2008) NLR, the nucleotide-binding domain leucine-rich repeat containing gene family. Curr Opin Immunol 20:3-9.

Yilmaz G, Granger DN (2008) Cell adhesion molecules and ischemic stroke. Neurol Res 30:783-793.

Yu J, Zhu H, Gattoni-Celli S, Taheri S, Kindy MS (2016) Dietary supplementation of GrandFusion $\left({ }^{\circledR}\right)$ mitigates cerebral ischemia-induced neuronal damage and attenuates inflammation. Nutr Neurosci 19:290-300.

Zhang L, Zhang ZG, Zhang RL, Lu M, Krams M, Chopp M (2003) Effects of a selective CD11b/CD18 antagonist and recombinant human tissue plasminogen activator treatment alone and in combination in a rat embolic model of stroke. Stroke 34:1790-1795.

Zhang RL, Chopp M, Jiang N, Tang WX, Prostak J, Manning AM, Anderson DC (1995) Anti-intercellular adhesion molecule-1 reduces ischemic cell damage after transient but not permanent middle cerebral artery occlusion in the Wistar rat. Stroke 26:1438-1443.

Zhaolin Z, Guohua L, Shiyuan W, Zuo W (2019) Role of pyroptosis in cardiovascular disease. Cell Prolif 52:e12563. 